
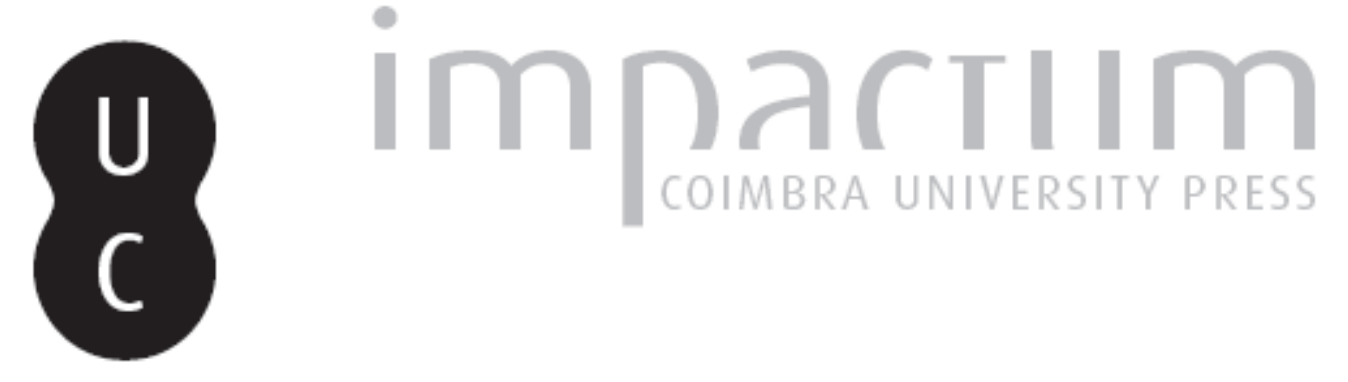

\title{
Nuno Mendes (?-1071): o último conde de Portucale
}

Autor(es): $\quad$ Gouveia, Mário de

Publicado por: $\quad$ Faculdade de Letras da Universidade de Coimbra, Instituto de História Económica e Social

URL

persistente:

URI:http://hdl.handle.net/10316.2/33464

DOI:

DOI:http://dx.doi.org/10.14195/0870-4147_44_7

Accessed : $\quad$ 26-Apr-2023 13:11:05

A navegação consulta e descarregamento dos títulos inseridos nas Bibliotecas Digitais UC Digitalis, UC Pombalina e UC Impactum, pressupõem a aceitação plena e sem reservas dos Termos e Condições de Uso destas Bibliotecas Digitais, disponíveis em https://digitalis.uc.pt/pt-pt/termos.

Conforme exposto nos referidos Termos e Condições de Uso, o descarregamento de títulos de acesso restrito requer uma licença válida de autorização devendo o utilizador aceder ao(s) documento(s) a partir de um endereço de IP da instituição detentora da supramencionada licença.

Ao utilizador é apenas permitido o descarregamento para uso pessoal, pelo que o emprego do(s) título(s) descarregado(s) para outro fim, designadamente comercial, carece de autorização do respetivo autor ou editor da obra.

Na medida em que todas as obras da UC Digitalis se encontram protegidas pelo Código do Direito de Autor e Direitos Conexos e demais legislação aplicável, toda a cópia, parcial ou total, deste documento, nos casos em que é legalmente admitida, deverá conter ou fazer-se acompanhar por este aviso.

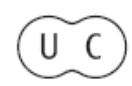




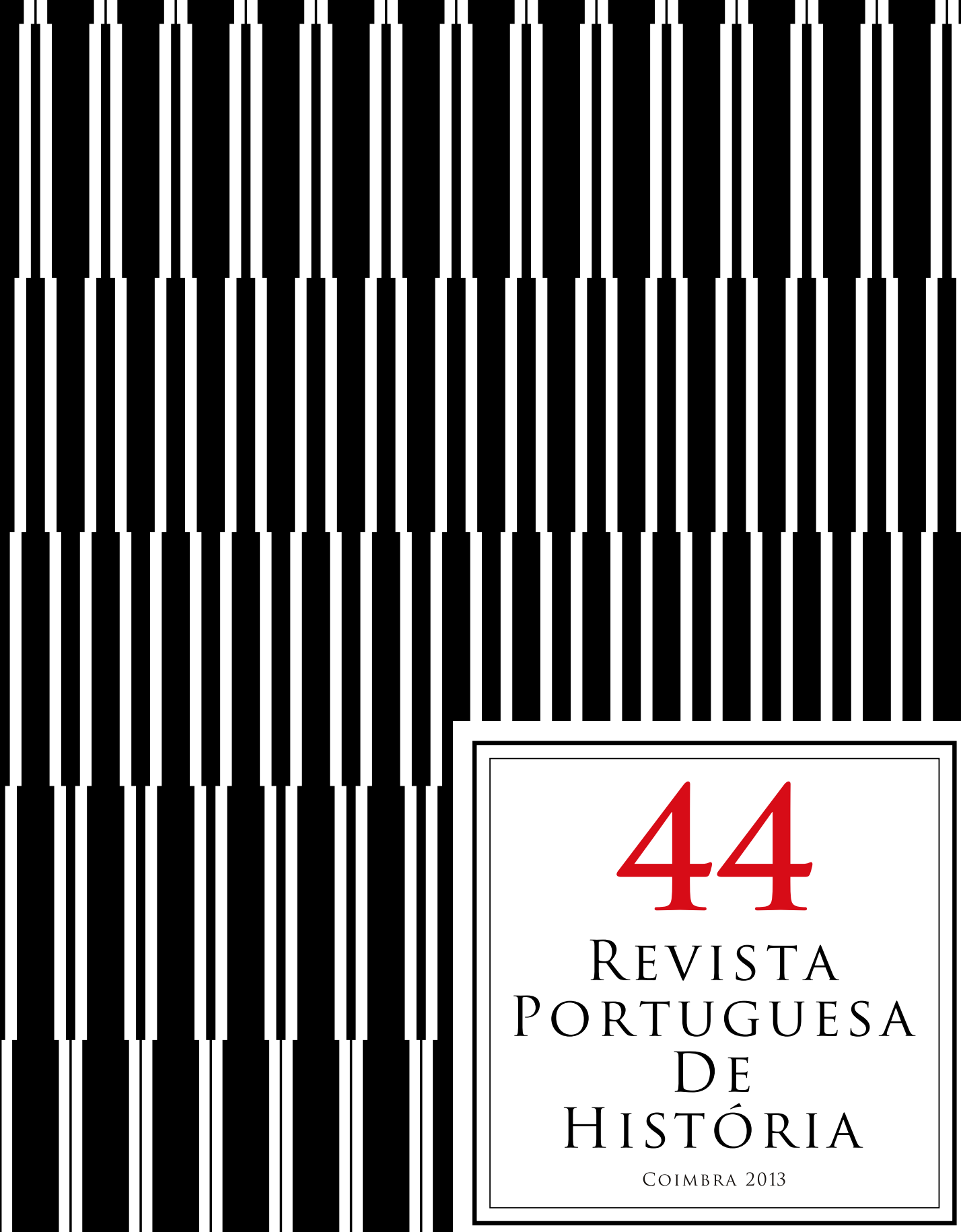




\title{
Nuno Mendes (?-1071): o último conde de Portucale
}

\author{
MÁrIo De Gouveia \\ Instituto de Estudos Medievais da Faculdade de Ciências Sociais e Humanas \\ da Universidade Nova de Lisboa. \\ gouveia.mnc@gmail.com
}

Resumo:

O objectivo deste artigo é apresentar uma reconstituição da biografia possível de Nuno Mendes, o último conde de Portucale (?-1071). A sua estrutura enfatiza os quatro vectores biográficos que podem ser sumariados com base na análise da documentação asturiano-leonesa dos séculos XI e XII, nomeadamente o Liber fidei da Sé de Braga: o conde, o proprietário, o juiz e o cabecilha. Parte substancial da matéria tratada diz respeito às relações entre Nuno Mendes e Garcia II, rei de Galiza e Portucale, bem como à batalha de Pedroso, em que o primeiro foi derrotado e morto.

\section{Palavras chave:}

Alta Idade Média (séc. XI); Entre-Douro-e-Minho; Condes de Portucale; Nuno Mendes; Biografia.
Abstract:

The aim of this essay is to present a reconstitution of the possible biography of Nuno Mendes, the last count of Portucale (?-1071). Its structure emphasizes the four biographical vectors that can be summarized based upon the analysis of the Asturleonese documentation of the $11^{\text {th }}$ and $12^{\text {th }}$ centuries, namely the Liber fidei of Braga's Cathedral: the count, the landowner, the judge and the rebeld. A substantial part of the subject respects to the relations between Nuno Mendes and Garcia II, king of Galicia and Portucale, as well as the battle of Pedroso, during which the former was defeated and died.

Keywords:

High Middle Ages (11 ${ }^{\text {th }}$ century); Entre-Douro-e-Minho; Counts of Portucale; Nuno Mendes; Biography. 


\section{As fontes}

Aquilo que é hoje possível saber-se da biografia de Nuno Mendes ${ }^{1}$, o último descendente masculino do presor e repovoador de Portucale nos finais do século IX, Vímara Peres, contemporâneo do rei Afonso III das Astúrias, provém de fontes muitos parcelares e lacunares. Mesmo se tivermos em conta as informações que se conservaram a respeito de outros representantes da família condal portucalense que viveram ou estão documentalmente atestados antes da época em que Nuno viveu ${ }^{2}$ - nomeadamente entre o século X e a primeira metade do XI-, podemos dizer que os dados que se lhe referem são escassos e provenientes de uma tipologia de fontes pouco variada. Estas correspondem a um conjunto de oito diplomas, dois dos quais conservados em duas variantes, outorgados num período que vai de 1059 a 1132 - mais concretamente a 31 de Dezembro de $1059^{3}, 16$ de Maio (?) de $1070^{4}, 17$ de Fevereiro de $1071^{5}$, 6 de Abril de $1072^{6}, 29$ de Abril de 10747, 11028, 27 de Julho de $1103^{9}$ e 28 de Setembro de $1132^{10}-$; ao qual se pode acrescentar uma perícope analística, incorrectamente datada de 18 de Janeiro de $1071^{11}$.

1 Contextualize-se, desde já, este estudo à luz do mais recente balanço sobre as investigações em história da nobreza medieval portuguesa, publicado em José Mattoso (with the collaboration of Leontina Ventura, José Augusto de Sottomayor-Pizarro and Bernardo Vasconcelos e Sousa), «The medieval Portuguese nobility», in The historiography of medieval Portugal (c. 1950-2010) (José Mattoso, director; Maria de Lurdes Rosa, Bernardo Vasconcelos e Sousa, Maria João Branco, editors), s.1., IEM - Instituto de Estudos Medievais, s.d., p. 401-423.

2 José Mattoso, «As famílias condais portucalenses dos séculos X e XI», in Obras completas, vol. 7: A nobreza medieval portuguesa. A família e o poder, s.l., Círculo de Leitores, 2001, p. $75-117$.

3 DC 421 (1059.12.31) (= CDF 111, de 1059.12.31).

4 DC 491 (1070.05?.16) (= Manuel Carriedo Tejedo, «Locus apostolicus (1012-1072), episcopi irienses (1014-1071) et Garsea rex in Gallecia (1066-1071/1072-1073)», Compostellanum. Revista de la archidiócesis de Santiago de Compostela. Sección de estudios jacobeos, vol. XLVI, n. ${ }^{\text {os } 3-4}$, Julho-Dezembro de 2001, p. 536, n. ${ }^{\circ} 139$ = Ermelindo Portela Silva, García II de Galicia .El rey y el reino (1065-1090), Burgos, Editorial La Olmeda, 2001, apênd. A, n. ${ }^{\circ}$ 6).

5 LF 253 (1071.02.17) (= Manuel Carriedo Tejedo, «Locus...», 2001, p. 538-539, n. ${ }^{\circ} 145$ ).

${ }^{6}$ LF 201 (1072.04.06).

7 LF 202 (1074.04.29).

${ }^{8}$ LF 315 e 643 (1102).

9 LF 173 (1103.07.27).

${ }^{10}$ LF 427 e 755 (1132.09.28).

${ }^{11}$ APV, Recensão longa de 1079, secção III, seg. Chronica Gothorum (ed. Pierre David, Lisboa-Paris, 1947, p. 298) (= Manuel Carriedo Tejedo, «Locus...», p. 539-540, n. ${ }^{\circ}$ 147). Faremos oportunamente a crítica da data desta perícope analística. 
Nuno encontra-se, por conseguinte, mencionado em cinco diplomas datados ou datáveis do século XI, e três, do XII. Estes integram o fundo arquivístico do mosteiro de S. João Baptista de Alpendurada e o códice diplomático da Sé de Braga conhecido pela designação de Liber fidei, para o qual foram transcritos depois de terem sido primeiramente copiados no Liber testamentorum I, pertencente à mesma sede catedralícia.

Dos oito diplomas acima referidos, três foram outorgados quando Nuno ainda era vivo, isto é, entre 1059 e $1071^{12}$; e os restantes cinco, já após a sua morte, ou seja, entre 1072 e $1132^{13}$, contendo, por este motivo, apenas referências a título póstumo. Nuno é ainda mencionado num texto de tipologia analística, compilado no mosteiro de St. ${ }^{\circ}$ Tirso de Riba de Ave, fundado e protegido pelos da Maia, por volta de 1079. São os Anais de St. ${ }^{\circ}$ Tirso de Riba de Ave, transmitidos em diferentes manuscritos, dos quais apenas um - a Chronica Gothorum - conserva a perícope relativa à batalha em que se faz o breve relato do confronto travado entre Nuno Mendes, conde de Portucale, e Garcia II, rei de Galiza e Portucale, no lugar de Pedroso, entre a cidade de Braga e o rio Cávado, incorrectamente datada de 18 de Janeiro de $1071^{14}$.

Estamos, pois, perante um corpus documental pouco significativo - quer em termos quantitativos, quer em termos qualitativos -, mas, ainda assim, fundamental para se poder reconstituir e compreender a biografia de Nuno. Tal como refere Avelino de Jesus da $\operatorname{Costa}^{15}$, a escassez de documentação referente à época em que Nuno viveu pode relacionar-se não só com as vicissitudes de conservação e transmissão das memórias de arquivo, como também com as características da tradição jurídica de origem germânica em vigor na Hispânia cristã pelo menos até aos finais do século XI - ou seja, até à época anterior à renovação dos estudos de Direito Romano, em que se alteraram substancialmente as práticas de conservação e transmissão de registos -, cujo sistema de provas e reivindicação de direitos se baseava mais no juramento oral, do que na outorga de instrumentos escritos. Em certa medida, foi o hábito de se entregarem os títulos comprovativos dos direitos

${ }^{12}$ DC 421 (1059.12.31) (= CDF 111, de 1059.12.31); DC 491 (1070.05?.16) (= Manuel Carriedo Tejedo, «Locus...», p. 536, n. ${ }^{\circ} 139$ = Ermelindo Portela Silva, García II..., apênd. A, n. ${ }^{\circ}$ 6); LF 253 (1071 .02.17) (= Manuel Carriedo Tejedo, «Locus...», p. 538-539, n. ${ }^{\circ} 145$ ).

${ }^{13}$ LF 201 (1072.04.06); LF 202 (1074.04.29); LF 315 e 643 (1102); LF 173 (1103.07.27); LF 427 e 755 (1132.09.28).

${ }^{14}$ APV, Recensão longa de 1079, secção III, seg. Chronica Gothorum (ed. Pierre David, Lisboa-Paris, 1947, p. 298) (= Manuel Carriedo Tejedo, «Locus...», p. 539-540, n. . 147).

${ }^{15}$ Dicionário de história da Igreja em Portugal, vol. I, Lisboa, 1980, s.v. «Arquivos eclesiásticos» (P. Avelino de Jesus da Costa), p. 521. 
de posse e usufruto entre contratantes, no momento em que se efectuava a transmissão de bens e propriedades em curso de alienação, junto com a posterior integração desses títulos jurídicos em códices diplomáticos para os quais eram parcial ou integralmente copiados, acompanhando a sua conservação nos respectivos tesouros, que levou a que chegassem até nós instrumentos escritos hoje considerados fundamentais para o conhecimento da história política do território de Entre-Douro-e-Minho ${ }^{16}$. Estamos, por este motivo, no tocante à documentação referente a Nuno, perante um corpus documental que foi sendo elaborado de forma mais ou menos espontânea por diferentes instituições sem ligação directa ao conde, parte da qual, aliás, reunida e integrada em fundos arquivísticos constituídos à margem de critérios orgânicos ${ }^{17}$.

A este conjunto de diplomas podemos juntar um último, datado de Julho de $1064^{18}$ - que a crítica taxou de falso -, o qual alegadamente teria pertencido ao fundo arquivístico do mosteiro de St. ${ }^{a}$ Maria de Lorvão no século XVI, mas que já não se encontrava nesta comunidade monástica quando Fr. Bernardo de Brito para aí se deslocou, na altura em que foi elaborado o respectivo inventário documental. Embora a cronologia a que é atribuído este diploma e os factos nele narrados - trata-se, no fundo, de uma extensa descrição da conquista de Coimbra aos Muçulmanos por Fernando I, em 1064, bem como dos privilégios concedidos por este rei a todos os que intervieram em seu favor na empresa militar, nomeadamente os monges laurbanenses - sejam compatíveis com a época em que Nuno viveu, a verdade é que o diploma está escrito em Castelhano e não há qualquer indício de que este possa eventualmente corresponder à tradução de um outro diploma anterior, porventura coevo dos acontecimentos nele narrados. Aliás, a minúcia descritiva que o caracteriza parece contrariar esta hipótese. Por nele se afirmar que Fernando I teria doado uma igreja situada em Coimbra aos monges laurbanenses e, simultaneamente,

${ }^{16}$ Dicionário..., s.v. «Arquivos eclesiásticos» (P. Avelino de Jesus da Costa), p. 525-526.

${ }^{17}$ Embora reconheçamos o valor instrumental e monumental dessa documentação, esta não é de forma alguma comparável às fontes orgânicas que se produziriam em Portugal a partir do século XIII, como os tombos e outras formas de registos cadastrais de domínio, enquanto instrumentos de gestão patrimonial, que, por definição, nos dão um retrato circunstanciado das estratégias de povoamento e organização social do espaço rural medieval. Se estes registos constituem verdadeiras unidades documentais que podem e devem ser analisadas à luz do seu contexto de produção e utilização, já os diplomas alusivos a Nuno provêm não só de diferentes instituições, como foram integrados em fundos sem qualquer relação entre si, com a agravante de, tanto num caso, como noutro, tais instituições reflectirem apenas uma visão monástica - e não régia, condal ou infancional - sobre o passado das sociedades que os produziram ou às quais foram expressamente destinados.

${ }^{18}$ CDF 70 (1064.07, falso). 
confirmado os direitos de posse e usufruto dos bens e propriedades que estes tinham desde tempos antigos, encomendando o mosteiro aos seus sucessores, somos levados a crer que este diploma tenha sido forjado com o intuito de o mosteiro poder reclamar, através da posse de um instrumento jurídico produzido ad hoc, direitos de posse e usufruto dos bens e propriedades supostamente doados à comunidade monástica pelo conquistador da cidade, num gesto de agradecimento pelos favores que aquele teria obtido durante o assédio, mantendo-se esta sob protecção régia mesmo após a sua morte, o que se confirma tendo em conta que os seus três filhos e sucessores - Afonso VI, Sancho II e Garcia II - também subscreveram o diploma. Registe-se que, à cabeça dos subscritores, surge o nome de «Nuño Mendez», que deve provavelmente identificar-se com Nuno. Mas trata-se de uma identificação sem interesse histórico, porque, como vimos anteriormente, o diploma não é autêntico.

Tendo em conta o que expusemos até agora, podemos, pois, afirmar que o corpus documental que serve de base para este estudo é constituído maioritariamente por diplomas avulsos ou integrados sob a forma de traslados em códices diplomáticos de origem monástica ${ }^{19}$ e eclesiástica ${ }^{20}$, todos eles provenientes de instituições situadas no território de Entre-Douro-e-Minho, outorgados entre as últimas décadas do século XI e as primeiras do XII, mas integrados nestes mesmos códices vários anos mais tarde. A documentação reparte-se actualmente entre vários arquivos do País, salientando-se, entre as colecções mais relevantes, as que se encontram depositadas nos Arquivos Nacionais/Torre do Tombo, em Lisboa, e no Arquivo Distrital de Braga. É aqui que encontramos a mais significativa parte das fontes que nos falam de Nuno, não obstante o facto de existirem vários outros diplomas, geralmente também conservados apenas sob a forma de apógrafos, transcritos e reunidos em códices diplomáticos, que nos permitem reconstituir e compreender o contexto histórico em que este viveu. A quantidade e a qualidade das informações que encontramos nestes fundos arquivísticos é, todavia, muito díspar. Como é evidente, esta disparidade reflecte as circunstâncias que nortearam a sua produção, traduzindo a maior ou menor importância social das figuras que intervieram, directa ou indirectamente, na sua elaboração.

${ }^{19}$ Dicionário..., s.v. «Arquivos eclesiásticos» (P. Avelino de Jesus da Costa), p. 533-541.

${ }^{20}$ Dicionário..., s.v. «Arquivos eclesiásticos» (P. ${ }^{e}$ Avelino de Jesus da Costa), p. 524-532. 


\section{O conde}

Nada sabemos acerca da infância e juventude de Nuno Mendes. Tudo o que se poderá dizer a este respeito não passará, pois, de mera especulação. No entanto, na sequência dos estudos efectuados por José Mattoso ${ }^{21}$ e A. de Almeida Fernandes ${ }^{22}$, conhecemos com bastante segurança as suas ligações familiares, bem como a natureza interna das suas relações de parentesco e consanguinidade ${ }^{23}$. Sabemos que o trisavô paterno de Nuno era Nuno Alvites ${ }^{24}$; os seus bisavós paternos, Alvito Nunes ${ }^{25}$ e Goncinha ${ }^{26}$; os seus avós paternos, Nuno Alvites ${ }^{27}$ e Ilduara Mendes ${ }^{28}$; e o seu pai, Mendo Nunes ${ }^{29}$. Nuno era, portanto, sobrinho de Gontrode Nunes ${ }^{30}$ e Múnio Nunes $^{31}$. Não consta que tivesse tido irmãos, embora tenha tido pelo menos um primo direito, Nuno Vasques, filho de Gontrode Nunes e Vasco. Dos seus antepassados maternos, contudo, nada sabemos, uma vez que desconhecemos o nome de sua mãe. Sabemos, no entanto, que Nuno era casado com Goncinha ${ }^{32}$, de quem teve pelo menos uma filha, Loba Nunes «Ouro Velido» ${ }^{33}$, que casou com Sesnando Davides, pais, por sua vez, de Elvira Sesnandes, mulher de Martim Moniz. Pormenor significativo sob o ponto de vista familiar: como neto de Nuno Alvites e Ilduara Mendes, Nuno era o representante, em segunda geração, da linhagem que se formou com a união das duas famílias condais portucalenses

${ }^{21}$ José Mattoso, «As famílias...»,p. 75-117.

${ }^{22}$ A. de Almeida Fernandes, «Que deve "Portugal" ao Porto?», «Notas às origens portucalenses (séculos V-XII)», «Território e política», in Portugal primitivo medievo, Arouca, Associação da Defesa do Património Arouquense, 2001, p. 151-207; 227-239 e 241-254; e 347-370 e 371-431, respectivamente.

${ }^{23}$ José Mattoso, «Ricos-homens, infanções e cavaleiros», in Obras completas, vol. 5: Ricos-homens, infanções e cavaleiros. Narrativas dos Livros de linhagens, s.l., Círculo de Leitores, 2001, p. 17-32 (sintetizados em José Mattoso, «A nobreza portucalense dos séculos IX a XI» e «Sobre a estrutura da família nobre portucalense, in Obras completas, vol. 7: A nobreza medieval portuguesa. A família e o poder, s.1., Círculo de Leitores, 2001, p. 191-201 e 271-283, respectivamente).

${ }^{24}$ José Mattoso, «As famílias...», p. 82-83, ref. ${ }^{\text {as }}$ I.C.3 e I.D.

${ }^{25}$ José Mattoso, «As famílias...», p. 83-84, ref. ${ }^{a}$ I.E.

${ }^{26}$ José Mattoso, «As famílias...», p. 84, ref. ${ }^{\text {a } I . E . ~}$

${ }^{27}$ José Mattoso, «As famílias...», p. 84 e 113, ref. ${ }^{\text {as }}$ I.E.1, I.F e IV.D.7.

${ }^{28}$ José Mattoso, «As famílias...», p. 84-85 e 113, ref. as I.F e IV.D.7.

${ }^{29}$ José Mattoso, «As famílias...», p. 85-86, ref. ${ }^{\text {as }}$ I.F.1 e I.G.

${ }^{30}$ José Mattoso, «As famílias...», p. 85, ref. ${ }^{\text {a I.F.2. }}$

${ }^{31}$ José Mattoso, «As famílias...», p. 85, ref. ${ }^{\text {a I.F.3. }}$

${ }^{32}$ José Mattoso, «As famílias...», p. 86, ref. ${ }^{\text {a I.H. }}$

${ }^{33}$ José Mattoso, «As famílias...», p. 86-87, ref. ${ }^{\text {as }}$ I.H e I.I. 
originárias dos descendentes de Vímara Peres ${ }^{34}$ - o antepassado de Nuno e Diogo Fernandes ${ }^{35}$ - o antepassado de Ilduara.

Ainda a propósito das suas ligações familiares, devemos notar que Nuno e Garcia II tinham um antepassado comum: Mendo Gonçalves ${ }^{36}$, filho de Gonçalo Mendes $^{37}$ e Ilduara Pais ${ }^{38}$, neto de Hermenegildo Gonçalves ${ }^{39}$ e Mumadona Dias $^{40}$, e, nessa qualidade, descendente de Diogo Fernandes. Os vínculos de parentesco que os uniam eram, contudo, ténues. Nuno descendia de Ilduara por intermédio do pai, Mendo Nunes, filho de Nuno Alvites; Garcia II, por sua vez, descendia de Elvira por intermédio da mãe, Sancha, mulher de Fernando I e irmã de Afonso V. Como Ilduara e Elvira eram irmãs, Nuno e Garcia II ainda mantinham relações de consanguinidade, ainda que longínquas: Nuno, pelo lado paterno, e Garcia II, pelo lado materno da família. Nessa qualidade, ambos pertenciam à terceira geração de descendentes de Mendo Gonçalves ${ }^{41}$, por serem ambos netos de irmãs.

Não podemos deixar de notar este facto, uma vez que ele nos ajuda a situar na escala do tempo histórico a data aproximada em que Nuno nasceu. Como é do conhecimento geral, a documentação da época não nos dá qualquer informação desta natureza, pelo que a análise das circunstâncias em que tal facto ocorreu depende mais da compreensão das ligações familiares entre Nuno e Garcia II, do que da reconstituição, hoje impossível, do seus primeiros anos de vida. É claro que o facto de Nuno e Garcia II terem pertencido à mesma geração de descendentes de Mendo Gonçalves não significa necessariamente que ambos tenham nascido na mesma altura. A data de nascimento de Garcia II é-nos

${ }^{34}$ José Mattoso, «As famílias...», p. 79, ref. ${ }^{\text {a I.A. }}$

35 José Mattoso, «As famílias...», p. 103-104, ref. a IV.A.

36 José Mattoso, «As famílias...», p. 110-112, ref. as IV.C.1 e IV.D.

37 José Mattoso, «As famílias...», p. 89, 107 e 109-110, ref. as II.B.5, IV.B.1 e IV.C.

38 José Mattoso, «As famílias...», p. 89 e 110, ref. ${ }^{\text {as }}$ II.B.5 e IV.C.

39 José Mattoso, «As famílias...», p. 96 e 106-107, ref. ${ }^{\text {as }}$ III.A.5.b e IV.B.

40 José Mattoso, «As famílias...», p. 106, ref. ${ }^{\text {as }}$ IV.A.4 e IV.B.

${ }^{41}$ Como é evidente, estas ligações familiares demonstram-nos que havia, de facto, uma proximidade entre o conde e o rei, ainda que fundamentada em relações de parentesco bastante frágeis. Estas ligações devem ter sido proporcionadas pelo papel de grande importância que Mendo Gonçalves desempenhou na cúria leonesa como tutor do príncipe Afonso - futuro rei Afonso V de Leão - entre os finais do século X e os inícios do XI, num contexto de afirmação da posição social do conde de Portucale face às ambições do conde de Castela. Com efeito, sabemos que, à medida que Mendo Gonçalves procurou estender a sua influência sobre os magnatas da cúria, Sancho Garcês tentou igualmente aproximar-se do herdeiro presuntivo do trono. Mendo Gonçalves conseguiu fazer valer os seus interesses sobre o rival numa contenda mediada por 'Abd al-Malik, filho de Muḥammad ibn Ab̄̄ 'Āmīr al-Manșūr, e logrou casar a sua filha, Elvira, com o jovem príncipe, selando desta forma uma aliança entre as famílias condal e régia. 
desconhecida, o mesmo acontecendo com a de Nuno. Neste caso, o método comparativo só poderá dar-nos uma data aproximada.

A generalidade dos historiadores tende a situar o nascimento de Garcia II por volta de 1040, ano que nos parece demasiado recente para se identificar com o de Nuno. De facto, se tivermos em conta que o conde já exercia funções públicas como representante de Fernando I numa assembleia judicial reunida em Palência, em 1059 - e é possível que Nuno tivesse participado, ao lado de sua avó, Ilduara Mendes, numa primeira assembleia judicial reunida em Guimarães, entre 1051 e 1052 -, parece-nos pouco provável que o conde tivesse nessa ocasião cerca de dezanove anos. É possível que Nuno tivesse participado nessa assembleia judicial ainda jovem, até por se tratar do primeiro documento que se lhe refere directamente. Mas, dada a importância do cargo, que seguramente obrigaria o seu detentor a possuir alguma experiência no trato de assuntos judiciais, parece-nos pouco provável que Nuno tivesse então a mesma idade que Garcia II. Nesse caso, seríamos obrigados a recuar à década de trinta, senão mesmo antes, a sua data de nascimento, de forma a fazer com que, em 1059, Nuno tivesse mais de vinte anos. Assim sendo, é possível que Nuno fosse mais velho do que Garcia II, e que, à data da sua morte, tivesse quarenta, ou mais, anos de vida.

Trata-se, contudo, de uma hipótese de trabalho que não podemos comprovar, no actual estado das investigações. Tal como referimos há pouco, a mais recuada notícia que se lhe refere dá-o como parte integrante de uma assembleia judicial reunida em Palência, em 1059. Fosse qual fosse a sua idade na altura, Nuno estava em condições de assumir funções como representante da monarquia leonesa, ainda que não actuando isoladamente. Como se compreende, este facto só poderia ter ocorrido num quadro de maioridade etária, o que corroboraria a hipótese que propusemos acima. Nestas circunstâncias, a consideração da mais reduzida faixa etária provável - os cerca de vinte anos - levar-nos-ia a situar no reinado de Bermudo III, algures entre 1028 e 1037, ou talvez ainda no de Afonso V, entre 999 e 1028, a sua data de nascimento. É, pois, possível que Nuno tenha nascido e crescido na conjuntura de crise que afectou a monarquia leonesa entre os finais do século X e os inícios do XI, provocada pelo recrudescimento das incursões militares muçulmanas no território de Entre-Minho-e-Mondego, sob a liderança de Muḥammad ibn Abī 'Āmīr al-Manșūr, bem como pela subida ao trono de Bermudo III, coincidente com a regência da madrasta, Urraca, e o agravamento dos conflitos que este rei manteve com Sancho III de Navarra.

Se dispomos de algumas informações que nos permitem reconstituir a ascendência paterna de Nuno, a verdade é que não subsiste nenhum elemento sobre a sua ascendência materna. A documentação que nos fala de Mendo Nunes tende apenas a citar o seu nome, sem mencionar o da respectiva mulher. 
Para além disso, a inexistência de qualquer notícia, ainda que indirecta, sobre a formação ou a distribuição do património materno - que poderia ter sido herdado por Nuno, o que nos permitiria rastrear a sua ascendência a partir da análise comparativa da sua área de concentração ou dispersão geográfica - também não nos permite sustentar qualquer hipótese sobre quem possa ter sido a sua mãe. $\mathrm{O}$ escasso património que Nuno recebeu em herança parece estar relacionado apenas com o lado paterno da família. A documentação dá-nos indícios de que foram a avó, Ilduara Mendes, e a tia, Gontrode Nunes, as duas proprietárias de fracções de terra que acabaram por ser herdadas por Nuno. Tal facto não quer dizer que Nuno possivelmente não tenha herdado outras propriedades. Possivelmente, apenas os títulos daquelas foram conservados através da sua cópia no Liber fidei.

A documentação de que dispomos para estudar o percurso de vida de Nuno não coincide com as fontes de informação conservadas sobre a sua filha, Loba Nunes, a qual é ainda mais escassa. Embora casada com uma das mais importantes autoridades da época, Sesnando Davides, representante da monarquia leonesa e, na qualidade de cônsul responsável pelo governo da cidade de Coimbra e autoridade dominante no território de Entre-Douro-e-Mondego, quer durante o reinado de Fernando I, quer durante o reinado de Afonso VI, Loba Nunes não é, à semelhança do pai, uma figura acerca da qual subsista um manancial significativo de informações. Tudo o que sobre ela sabemos provém basicamente dos diplomas que registam a acção do pai ou do marido.

Apesar das dificuldades que a documentação nos levanta, há um dado que nos parece digno de nota, uma vez que nos remete para a forma como se processavam os vínculos de identificação e coesão comunitárias no seio da família condal portucalense: a onomástica. A reconstituição da genealogia de Nuno permite-nos chegar à conclusão de que o seu nome próprio já tinha sido atribuído a pelo menos duas outras gerações da família, nomeadamente ao seu avô, Nuno Alvites, e ao seu trisavô, também chamado Nuno Alvites. Se tivermos em conta outros exemplos, verificamos que não se trata de um caso isolado. É importante termos em conta este aspecto, uma vez que ele parece reforçar a ligação entre o herdeiro presuntivo do condado e os seus ascendentes paternos, tendo como referência duas gerações intercaladas. A adopção do nome pessoal parece, assim, dar resposta a uma estratégia de enaltecimento da memória familiar característica dos grupos nobres, que nos ajuda a compreender a existência de mecanismos de afirmação social no interior destes grupos, por comparação a outras famílias de condição social diferenciada.

Simultaneamente, devemos notar que o nome de Nuno é sempre acompanhado pelo uso do título de «conde» (comes). O uso deste título reflecte não 
só o carácter privilegiado da condição nobre da sua família, mas também o reconhecimento da sua legitimidade como representante nominal da monarquia leonesa no território de Entre-Douro-e-Minho. Nos vários actos da prática que o referem, Nuno é sempre identificado como tal. A análise do quadro que se segue é, quanto a este aspecto, bastante esclarecedora:

Quadro n. ${ }^{\circ} 1$ - Diplomas com referência à condição nobre de Nuno Mendes (séc. XI-XII)

\begin{tabular}{|c|c|c|c|c|}
\hline $\begin{array}{l}\text { Data do } \\
\text { diploma }\end{array}$ & Título & Contexto & Referência & Fonte \\
\hline 1059.12 .31 & $\begin{array}{c}\text { Sem ref. } .^{\text {a }}(\ll \text { Nunu } \\
\text { mendiz») }\end{array}$ & $\begin{array}{c}\text { Julgamento na corte } \\
\text { de Fernando I, em } \\
\text { Palência }\end{array}$ & $\begin{array}{l}\text { Referência à presença } \\
\text { do conde de Portucale } \\
\text { na assembleia judicial }\end{array}$ & $\begin{array}{c}\text { DC } 421(=\mathrm{CDF} \\
111 \text {, de } 1059.12 .31)\end{array}$ \\
\hline 1070.05 .16 & $\begin{array}{c}\text { Conde («Nunno } \\
\text { menindiz comes») }\end{array}$ & $\begin{array}{c}\text { Doação de Garcia II } \\
\text { a Afonso Ramires, } \\
\text { dos de Riba Douro }\end{array}$ & $\begin{array}{l}\text { Subscrição do conde de } \\
\text { Portucale, na qualidade } \\
\text { de confirmante }\end{array}$ & \begin{tabular}{|} 
DC 491 (= Carriedo \\
Tejedo, 2001, \\
p. 536, n. ${ }^{\circ} 139=$ \\
Portela Silva, 2001, \\
apênd. A, n. ${ }^{\circ}$ 6) \\
\end{tabular} \\
\hline 1071.02 .17 & $\begin{array}{c}\text { Conde }(« \text { comes } \\
\text { Nunnus } \\
\text { Menendiz», } \\
\text { «Nunnus comes») }\end{array}$ & \begin{tabular}{|c|} 
Doação de Nuno \\
Mendes ao mosteiro \\
de St. ${ }^{\circ}$ Antonino de \\
Barbudo
\end{tabular} & Outorgante da doação & $\begin{array}{c}\text { LF } 253 \text { (= Carriedo } \\
\text { Tejedo, 2001, } \\
\left.\text { p. 538-539, n. } .^{\circ} 145\right)\end{array}$ \\
\hline 1072.04 .06 & $\begin{array}{c}\text { Conde («comite } \\
\text { Nuno Menendiz») }\end{array}$ & $\begin{array}{c}\text { Doação de Gontrode } \\
\text { Nunes a Eita } \\
\text { Gondesendes e } \\
\text { Elvira Gonçalves }\end{array}$ & $\begin{array}{l}\text { Referência ao conde } \\
\text { de Portucale, a título } \\
\text { póstumo, como } \\
\text { proprietário de bens na } \\
\text { vila de Nogueiró }\end{array}$ & LF 201 \\
\hline 1074.04 .29 & $\begin{array}{l}\text { Conde }(\ll \text { comite } \\
\text { Nunnu } \\
\text { Menendiz») }\end{array}$ & $\begin{array}{c}\text { Doação de } \\
\text { Sesnando Davides } \\
\text { e Loba Nunes a } \\
\text { Eita Gondesendes e } \\
\text { Elvira Gonçalves } \\
\end{array}$ & $\begin{array}{l}\text { Referência ao conde } \\
\text { de Portucale, a título } \\
\text { póstumo, como } \\
\text { proprietário de bens na } \\
\text { vila de Nogueiró }\end{array}$ & LF 202 \\
\hline 1102 & $\begin{array}{c}\text { Conde («comite } \\
\text { Nunnus } \\
\text { Menendiz») }\end{array}$ & \begin{tabular}{|} 
Notícia da fundação \\
e dotação do \\
mosteiro de St. ${ }^{\circ}$ \\
Antonino de \\
Barbudo
\end{tabular} & $\begin{array}{l}\text { Referência ao conde } \\
\text { de Portucale, a título } \\
\text { póstumo, como } \\
\text { proprietário de bens na } \\
\text { vila de Barbudo }\end{array}$ & LF 315 e 643 \\
\hline 1103.07 .27 & $\begin{array}{l}\text { Conde («Nuno } \\
\text { Menendiz», } \\
\text { «Nunum } \\
\text { Menendiz», } \\
\text { «comite Nuno } \\
\text { Menendiz») } \\
\end{array}$ & $\begin{array}{c}\text { Doação de Toda } \\
\text { Eitaz à Sé de Braga }\end{array}$ & $\begin{array}{c}\text { Referência ao conde } \\
\text { de Portucale, a título } \\
\text { póstumo, como } \\
\text { proprietário de bens } \\
\text { nas vilas de Gualtar e } \\
\text { Barros }\end{array}$ & LF 173 \\
\hline
\end{tabular}




\begin{tabular}{|c|c|c|c|c|}
\hline $\begin{array}{c}\text { Data do } \\
\text { diploma }\end{array}$ & Título & Contexto & Referência & Fonte \\
\hline 1132.09 .28 & $\begin{array}{c}\text { Conde («comite } \\
\text { Nuno Menendi») }\end{array}$ & $\begin{array}{c}\text { Doação de Afonso } \\
\text { Henriques a Rodrigo } \\
\text { Peres }\end{array}$ & $\begin{array}{c}\text { Referência ao conde } \\
\text { de Portucale, a título } \\
\text { póstumo, como } \\
\text { proprietário de bens na } \\
\text { vila de Várzea de Beiral }\end{array}$ & LF 427 e 755 \\
\hline
\end{tabular}

Como se vê, a primeira referência que atesta o uso do título de «conde» por Nuno não coincide com o seu aparecimento nas fontes diplomáticas ${ }^{42}$. Nuno só é designado nessa qualidade em $1070^{43}$ e $1071^{44}$. Cinco outras referências a Nuno em fontes de idêntica tipologia, com datas oscilantes entre $1072 \mathrm{e}$ $1132^{45}$, recordam a sua memória em associação ao título de «conde», embora a título póstumo. A única perícope relativa a Nuno que encontramos numa fonte analística também o associa ao título de «conde» ${ }^{46}$. Estes mesmos diplomas omitem o qualificativo de «senhor» (dominus), reconhecido quando se fala de Goncinha, sua mulher, citada, em 1071 ${ }^{47}$, como «condessa» (comitissa) e «senhora» (domina). Podemos, portanto, dizer que Nuno parece beneficiar de um tratamento público consentâneo com a sua condição social, patente não só nos actos em que se regista o uso pessoal do título de «conde» - o que nos revela a clara consciência que Nuno tinha da sua condição nobre ${ }^{48}-$, mas também nos actos em que lhe é reconhecido, por terceiros, o direito ao uso do título de «conde».

Como último descendente masculino do presor e repovoador de Portucale, Vímara Peres, Nuno pertencia, pois, a uma das famílias da nobreza condal portucalense com ligações à família régia asturiano-leonesa, instalada no território de Entre-Douro-e-Minho nos finais do século IX. O seu prestígio radicava em grande medida no facto de os seus membros terem desempenhado

${ }^{42}$ DC 421 (1059.12.31) (= CDF 111, de 1059.12.31).

${ }^{43}$ DC 491 (1070.05.16) (= Manuel Carriedo Tejedo, «Locus...», p. 536, n. ${ }^{\circ} 139=$ Ermelindo Portela Silva, García II..., apênd. A, n. ${ }^{\circ}$ 6).

${ }^{44}$ LF 253 (1071.02.17) (= Manuel Carriedo Tejedo, «Locus...», p. 538-539, n. $\left.{ }^{\circ} 145\right)$.

${ }^{45}$ LF 201 (1072.04.06); LF 202 (1074.04.29); LF 315 e 643 (1102); LF 173 (1103.07.27); e LF 427 e 755 (1132.09.28).

${ }^{46}$ APV, Recensão longa de 1079, secção III, seg. Chronica Gothorum (ed. Pierre David, Lisboa-Paris, 1947, p. 298) (= Manuel Carriedo Tejedo, «Locus...», p. 539-540, n. . 147).

${ }^{47}$ LF 253 (1071.02.17) (= Manuel Carriedo Tejedo, «Locus...», p. 538-539, n. . 145).

${ }^{48}$ Este facto reflecte-se nos actos de confirmação de diplomas per manum propriam, como acontece a 16 de Maio (?) de 1070 (DC 491, de 1070.05?.16: «Nunno menindiz comes conf.» = Portela Silva, 2001, apênd. A, n. ${ }^{\circ}$ 6) e a 17 de Fevereiro de 1071 (LF 253, de 1071.02.17: «Nunnus comes» (= Carriedo Tejedo, 2001, p. 538-539, n. $\left.{ }^{\circ} 145\right)$. 
funções como representantes nominais da monarquia leonesa na região, não obstante o clima de crescente rivalidade que marcou as relações entre os condes e os infanções sobretudo ao longo das últimas décadas do século XI. Embora nascido e crescido numa conjuntura de crise política, Nuno deve ter conseguido alargar a sua rede de solidariedades no território de Entre-Douro-e-Minho quando casou com Goncinha, com quem teve uma filha, Loba Nunes, cujo casamento com Sesnando Davides, o governador do território de Entre-Douro-e-Mondego, teve provavelmente como objectivo estender a sua influência a uma região que escapava às ambições dos seus mais poderosos rivais, como Garcia II, cuja autoridade se alargava às famílias de infanções que ocupavam as franjas dos territórios nominalmente administrados por Nuno. A verdade é que, durante a sua vida, Nuno parece ter-se mostrado sempre consciente da sua condição nobre, usando, à semelhança dos seus antepassados, o título de «conde», cujo uso lhe foi igualmente reconhecido por terceiros. Como é evidente, tal facto não pode deixar de apontar para a posição social de destaque que ainda lhe era reservada nas vésperas da sua morte.

\section{O juiz}

Nada sabemos sobre o que se passou com Nuno Mendes até aos meados do século XI. A partir daqui, passamos a dispor de mais informações sobre a sua vida. Com efeito, é provável que Nuno tenha participado numa primeira assembleia judicial reunida em Guimarães, entre 1051 e 1052, antes da sua deslocação para Palência, em 1059. Deste primeiro procedimento judicial nada nos resta, a não ser uma breve referência num diploma conservado no Liber fidei pela qual ficamos a saber que Toda Eitaz doou à Sé de Braga, a 27 de Julho de $1103^{49}$, com certas obrigações, três quartas partes das vilas de Nogueiró e St. ${ }^{\text {a }}$ Tecla, para além de outros bens nas vilas de Dadim, Cerqueda, Gualtar e Barros, todos na região de Braga, reservando para si um terço desses bens, enquanto fosse viva.

Nuno já tinha falecido nessa altura, pelo que é recordado nesse diploma como pai de Loba Nunes e sogro de Sesnando Davides, os quais haviam vendido a Eita Gondesendes e sua mulher, Elvira Gonçalves, pais de Toda Eitaz, alguns bens em Nogueiró, metade dos quais tinham estado na posse de Gontrode Nunes. Nuno é também recordado como patrono da igreja de S. Miguel de Gualtar e detentor da terça parte dos respectivos direitos, por incomuniação.

\footnotetext{
${ }^{49}$ LF 173 (1103.07.27).
} 
Um curto parágrafo em apêndice ao diploma menciona o facto de Toda Eitaz ter contemplado na sua doação à Sé de Braga as herdades e casas que haviam pertencido a Guilhifonso Alvites e que este teria dado a Nuno, como multa pelo homicídio do saião de Caldas [de Vizela]. Sabemos que, por este homicídio, Nuno recebeu ainda metade das herdades que este possuía em Barros.

Embora sem mencionar a data do acontecimento, o diploma dá-nos informações suficientes para que o possamos relacionar com outro diploma copiado no Liber fidei, em que Guilhifonso Alvites é mencionado como tendo estado envolvido numa contenda judicial a propósito de um caso de homicídio. A não ser que se trate de uma figura diferente ou de uma outra contenda relativa à mesma figura - facto improvável, tendo em conta que se trata de um homónimo proprietário de bens em Gualtar, envolvido em circunstâncias idênticas às relatadas no diploma anterior -, é possível relacionar os dois diplomas e, desta forma, propor como data aproximada para a celebração do acordo judicial com Nuno os inícios de 1052 ou, com maior propriedade, os finais de 1051. Com efeito, data-se dos primeiros dias daquele ano, mais concretamente de 3 de Janeiro de $1052^{50}$, o registo pelo qual Guilhifonso Alvites e sua mulher, Mania «Ermesenda», cederam a Ilduara Mendes metade das herdades que possuíam em Gualtar, no território de Braga, junto ao rio Este, com as suas casas de pedra e de madeira, para além de algumas séssegas de moinhos e canais de água, entre soutos, linhares, pomares e vinhas, por a condessa ter pago quinhentos soldos em satisfação da pena imposta ao primeiro pelo crime de homicídio.

Segundo o diploma, uma vez cometido o crime, Guilhifonso Alvites foi preso e interrogado pelos meirinhos de Fernando I, entre os quais Gomes Échigues. O homicida apelou a Ilduara Mendes, e, num simbólico gesto de respeito, caiu aos pés da condessa e de sua mãe, Tutadona, suplicando-lhes ajuda. De forma a resolver o diferendo, Ilduara Mendes determinou que as partes implicadas no litígio se reunissem em Guimarães, numa assembleia a que teriam comparecido Gomes Échigues e Paio Mides, meirinhos do rei, para além de Osório Teles, Gonçalo Raupariz e Pedro Alvites, abade do mosteiro de St. ${ }^{a}$ Maria de Guimarães, bem como o seu prioste homónimo, entre outros representantes da família condal portucalense. Durante a sessão, ficou estabelecido entre a condessa e os meirinhos que Ilduara Mendes lhes daria, como satisfação da pena imposta a Guilhifonso Alvites, bens diversos avaliados em quinhentos soldos, em troca de metade dos bens que este possuía em Gualtar.

${ }^{50}$ LF 184 (1052.01.03). 
Embora Nuno não seja mencionado nos sincronismos do diploma, subscrito por vários confirmantes leigos, é possível relacionar este acontecimento com o mencionado na carta relativa a Toda Eitaz. Conforme salientámos anteriormente, as figuras envolvidas no litígio são as mesmas e as circunstâncias em que ele ocorreu parecem apontar no mesmo sentido. O que nos parece interessante destacar neste caso é o facto de a assembleia judicial de Guimarães ter sido possivelmente presidida por Ilduara Mendes, numa altura em que esta se encontraria a definir uma política de aquisição sistemática de bens na região de Braga suportando o crescimento do paço de Nogueiró, seu local de residência, como unidade de exploração agrária. Uma vez que Nuno veio a estabelecer um acordo com Guilhifonso Alvites, através do qual acabou por obter bens na posse do alegado homicida, é possível que o conde já tivesse nessa altura alguma ligação ao procedimento judicial, assistindo, eventualmente, às sessões presididas pela condessa e os meirinhos do rei. Trata-se, contudo, de uma hipótese por averiguar. Tal facto poderia compreender-se se a resolução do diferendo tivesse ocorrido apenas depois da morte de Ilduara Mendes - cuja data não conhecemos com exactidão, mas sabemos ser anterior a 1058 -, levando a que o desfecho do procedimento iniciado durante a administração de sua avó tivesse acontecido num momento em que Nuno já tivesse assumido o governo do condado, ou seja, entre 1052 e 1053 . Com efeito, este último ano coincide com o terminus ante quem para a data de ocorrência da morte de Mendo Nunes e o início do governo do condado por Nuno. Nestas circunstâncias, é possível que a participação de Nuno na assembleia judicial de Palência não corresponda ao seu primeiro acto público como representante nominal da monarquia leonesa no território de Entre-Douro-e-Minho. Nuno devia governar o condado pelo menos desde os finais de 1051, ainda que sob a tutela de Ilduara Mendes.

Embora este episódio nos dê algumas pistas sobre o momento em que Nuno provavelmente assumiu o governo do condado e passou a desempenhar funções no plano judicial, como representante nominal da monarquia leonesa no território de Entre-Douro-e-Minho, o mais significativo testemunho de que Nuno passou a ser parte activa na vida política da região corresponde a um diploma que nos fala da sua participação numa segunda assembleia judicial, decorrida provavelmente ao longo das últimas semanas de $1059^{51}$, motivada pela apropriação indevida de bens alegadamente pertencentes ao mosteiro de S. Martinho de Soalhães.

\footnotetext{
${ }^{51}$ DC 421 (1059.12.31) (= CDF 111, de 1059.12.31).
} 
O número de diplomas outorgados por Fernando I neste ano é escasso. Exceptuando o relativo a este litígio, em nenhum dos diplomas expedidos ao longo de 1059 se detecta a presença dos condes e dos infanções que estiveram em Guimarães poucos anos antes. A 1 de Junho de $1059^{52}$, Fernando I e Sancha outorgaram ao mosteiro de S. Salvador de Oña e ao seu abade Énego a vila de Condado, fundada sobre o rio Ebro, com todas as suas pertenças e privilégio de imunidade. Quatro meses mais tarde, a 1 de Outubro $^{53}$, efectuaram uma permuta com Fruílhe Guterres e os seus filhos contemplando metade da vila de Castro, nas margens do rio Cea, que havia pertencido a Fernando Pais, filho de Paio Rodrigues, a quem haviam sido confiscados todos os bens por se ter rebelado contra Afonso V, ao ter fugido com a filha de Sancho Gomes e não ter querido casar com a filha de Múnio Rodrigues, contra a determinação do rei. A 26 de Dezembro ${ }^{54}$, poucos dias antes de ser lavrado o diploma que atestava a sentença do colectivo reunido a propósito da queixa levantada pelos presbíteros do mosteiro de Soalhães, concederam privilégio confirmando ao bispo Mirão de Palência todas as posses e direitos outorgados pelo pai, Sancho III, determinando igualmente os limites da diocese palentina, com o objectivo de se pôr termo às contendas entre os bispos de Leão e Castela, Alvito e Gomes, respectivamente, e o mencionado Mirão.

O facto de este documento conter algumas expressões muito pouco comuns na diplomática fernandina obriga-nos a levantar algumas dúvidas quanto à sua autenticidade: é possível que tenham sido feitas interpolações tardias aos registos originais. Seja como for, convém sublinhar que, neste último caso, estamos perante o diploma outorgado por Fernando I que antecede imediatamente a sentença judicial proferida a favor do mosteiro de Soalhães. A particularidade desse diploma reside no facto de corresponder a um privilégio outorgado em benefício da sede eclesiástica de Palência, localidade situada junto ao Carrión, afluente da margem direita do rio Douro, incorporada no condado de Castela após o fraccionamento dos domínios territoriais de Sancho III, onde provavelmente ainda se encontrariam - ou, pelo menos, teriam estado - Nuno e o seu primo direito, Nuno Vasques, bem como três dos infanções portucalenses documentados nos anteriores diplomas, Gomes Échigues, dos de Sousa, Mendo Gonçalves, dos da Maia, e Godinho Viegas, dos de Azevedo. Nele se relatam as circunstâncias da destruição e posterior restauração da igreja diocesana, acompanhada pela concessão de privilégios aos bispos Pôncio,

\footnotetext{
${ }^{52}$ CDF 52 (1059.06.01).

${ }^{53}$ CDF 53 (1059.10.01).

${ }^{54}$ CDF 54 (1059.12.26).
} 
Bernardo e Mirão; mas nada se nos é dito acerca de outras situações judiciais em que o rei pudesse ter estado envolvido na altura. Sabemos apenas que este diploma foi subscrito por Fernando I, Sancha e os seus filhos, Sancho, Afonso, Garcia, Urraca e Elvira, para além de alguns prelados de origem leonesa, castelhana e galega, bem como por vários nobres da corte, alguns dos quais identificados como condes, outro, como alferes, e ainda outro, como mordomo ${ }^{55}$. Está omisso o nome de Nuno e os dos infanções portucalenses.

O diploma que atesta a existência do litígio relativo ao mosteiro de Soalhães foi lavrado no quadro de uma assembleia judicial constituída pelo rei com o objectivo de se dar resolução à questão levantada pouco antes pela comunidade monástica, a propósito da necessidade de se confirmarem os seus direitos de posse e usufruto sobre uma propriedade - o documento diz tratar-se genericamente de uma «herdade» - situada no território de Entre-Douro-e-Minho e contestada em sede de litígio por Garcia Moniz ${ }^{56}$, dos de Riba Douro. O diploma está datado de 31 de Dezembro de 1059. Infelizmente, é parco em detalhes sobre as circunstâncias que despoletaram o conflito $^{57}$. O formulário utilizado não

${ }^{55}$ CDF 54 (1059.12.26): «Ego Fredinandus, nutu diuino rex, qui ista carta scribere mandaui, de manu mea hoc meum edictum roboraui / hoc signo et confirmo (monogramma: FRE).»; «Ego regina Sancia conf.»; «Sancius illorum filius conf.»; «Aldefonsus similiter conf.»; «Garsias similiter conf.»; «Urraka regis proles conf.»; «Geluira idem conf.»; «Aluitus legionensis episcopus conf.»; «Gomesanus castellanensis Bardulie conf.»; «Maurelle lucensis episcopus conf.»; «Flaginus comes conf.», «Perus (sic) comes conf.»; «Ordonius armiger regis conf.»; «Guter Eguderiz maiordomus conf.».

${ }^{56}$ Garcia Moniz, senhor da família dos de Riba Douro - que teve como primeiro representante Mónio Viegas, vindo da Gasconha com dois irmãos, Sesnando, bispo do Porto, e Énego, segundo os livros de linhagens -, está documentado entre 1047 e 1061. Embora não seja fácil caracterizar a evolução das terras que estiveram na posse de sua família, devido à multiplicidade de ramos em que se dividiam, sabe-se que Garcia Moniz era tenente da terra de Penafiel de Sousa, e que, durante o seu governo, a tenência dessa terra estava associada à de Benviver, entre os rios Douro e Tâmega. Se a primeira passou directamente para o seu neto, Egas Ermiges, que lhe associou também o governo das de Arouca e Lamego, a segunda terá sido recebida primeiro pelo seu sobrinho, Mónio Viegas, antes de vir a ser assimilada por aquele. Os senhores de Riba Douro exerciam, portanto, a sua autoridade sobre o curso médio do rio Douro, sobretudo depois que Egas Ermiges passou a deter jurisdição sobre Lamego, na dependência de Sesnando Davides, sendo sucedido nas funções pelo genro deste e primo afastado daquele, Martim Moniz, governador de Coimbra e companheiro de armas do Cid, em Valência (José Mattoso, «Ricos-homens...», p. $44,67,68$ e 96$)$.

${ }^{57}$ Sobre os procedimentos jurídicos utilizados na resolução de conflitos acerca de direitos de posse e usufruto da terra entre mosteiros e infanções, no quadro da afirmação dos poderes de tipo senhorial, leia-se Reyna Pastor, Resistencias y luchas campesinas en la época del crecimiento y consolidación de la formación feudal. Castilla y León, siglos X-XIII, Madrid, Siglo Veintiuno de España Editores, S.A., 1993, p. 52-55, 56-74, 80-83 e 100-112. 
só suscita várias dúvidas quanto à reconstituição material dos factos, dado o carácter padronizado das cláusulas diplomáticas, como reflecte uma fase do processo que corresponde já à aplicação da sentença proferida pela assembleia judicial, ou seja, o termo do litígio. As razões que estiveram na origem das divergências entre as partes litigantes, tal como os procedimentos seguidos na tramitação do processo, são-nos, por isso, parcialmente desconhecidas.

O diploma limita-se a referir-nos que os presbíteros Afonso e João se deslocaram a Castela, mais concretamente a Palência, com o objectivo de apresentar provas contra Garcia Moniz numa questão relacionada com a posse da supra-citada herdade.

Conduzidos por mão de Diogo Trutesendes, Mendo Dias e Gosendo Araldes, vigários de Fernando I, os dois presbíteros apresentaram-se perante uma assembleia constituída por algumas das mais altas figuras da hierarquia social do reino, sem dúvida os principais apoiantes da política fernandina em assuntos relativos ao território de Entre-Douro-e-Minho: por um lado, os condes Sancho Vasques, Pôncio, Nuno Vasques e Nuno Mendes; e, por outro, os infanções portucalenses Gomes Échigues ${ }^{58}$, Mendo Gonçalves ${ }^{59}$ e Godinho $^{-}$

${ }^{58}$ Gomes Échigues, filho de Échega Vizóis e neto de Vizói Vizóis, ascendente da família dos de Sousa, está documentado entre 1049 e 1072. Parece não ter ostentado nenhum título nobiliárquico, embora surja como imperador sob a autoridade do rei na terra de Aguiar de Sousa, num julgamento em 1050; como meirinho, juntamente com outros delegados de Fernando I, em 1052; e como infanção, num julgamento em 1059. As terras de Basto, Aguiar de Sousa e St. ${ }^{\text {a }}$ Cruz de Sousa, que estiveram na sua posse em regime de tenência, passaram para o seu filho, Egas Gomes, e, deste, para os respectivos descendentes. Deve também identificar-se com esta figura a personagem que faz uma doação acompanhada pela mulher e alguns filhos ao mosteiro de Pombeiro, em 1072. Entre os autores monásticos dos séculos XVI e XVII, Gomes Échigues era considerado como fundador deste mosteiro, facto verosímil à luz do contexto histórico regional (José Mattoso, «Ricos-homens...», p. 39, 66, 68 e 96).

${ }^{59}$ Mendo Gonçalves, ascendente da família dos senhores da Maia, encontra-se documentado entre 1045 e 1065 . Os Anais de St.$^{\circ}$ Tirso de Riba de Ave atribuem-lhe o prestigioso epíteto de «varão ilustre e de grande poder em todo Portucale». Sucedeu na linhagem dos infanções da Maia a Gonçalo Trastamires, seu pai, e a Trastemiro Alboazar, seu avô, filho, por sua vez, de Alboazar Lovesendes, o mais antigo membro que se conhece da família, que, com a sua mulher, Unisco Godins, fundou o mosteiro de St. ${ }^{\circ}$ Tirso de Riba de Ave, em 978. Ao longo de cerca de vinte anos, Mendo Gonçalves aparece várias vezes a presidir a pleitos judiciais, chegando a acompanhar Fernando I em três ocasiões, em 1049, 1053 e 1059, e tendo provavelmente participado na conquista de Coimbra por este rei, em 1064. Embora os seus interesses estivessem radicados a Sul do rio Douro, acabaram também por se orientar para a margem Norte do rio Ave, como resultado do seu casamento com Leodegúndia Soares, dos da Várzea, ascendente dos de Azevedo e dos de Baião. Foi tenente das terras de Refóios de Riba de Ave, de Vermoim e da Maia. Seu filho, Soeiro Mendes, atingiu na época grande poder e prestígio. Sua filha, Dórdia, casou 
Viegas $^{60}$, para além de outros não-especificados filhos de homens bem-nascidos; e ainda alguns bispos, como Alvito, Mauselo, Miro, Vistruário e Sesnando. O diploma ainda nos dá a entender que, uma vez apresentadas as causas, a assembleia se pronunciou a favor das reivindicações dos dois presbíteros. Com o objectivo de se pôr termo ao litígio, Fernando I proferiu a sentença a seu favor e ordenou que fossem confirmados os direitos de posse e usufruto da herdade reclamados por Afonso e João, determinando a obrigatoriedade de Garcia Moniz lhes reconhecer publicamente esses direitos através da outorga de uma carta de agnição, que veio a ser escrita por Ordonho ${ }^{61}$, subscrita pelas partes litigantes e confirmada, entre outros, pelas figuras presentes na assembleia judicial. Da lista de confirmantes formada por Fernando I, os vigários do rei, os condes e os infanções portucalenses, constam os nomes de Diogo Trutesendes, Mendo Dias e Gosendo Araldes, por um lado; de Sancho Vasques e Pôncio, por outro; e de Gomes Échigues, Mendo Gonçalves e Godinho Viegas ${ }^{62}$, entre numerosos outros leigos e religiosos. Estão, portanto, representadas as figuras que sabemos terem desempenhado parte activa no procedimento judicial. Ausentes, apenas os nomes de Nuno e Nuno Vasques.

Não sabemos se Nuno foi chamado a presidir à assembleia judicial reunida para pôr fim ao litígio por uma das partes implicadas na contenda, uma vez que o diploma não aponta neste sentido. Para além disso, Nuno não tinha qualquer ligação ao mosteiro de Soalhães, muito menos a Garcia Moniz.É, pois,

com Paio Guterres, dos da Silva, principal representante da autoridade régia em terras do Cávado pelo último quartel do século XI (José Mattoso, «Ricos-homens...», p. 17, 42, 66 e 96).

${ }^{60}$ Godinho Viegas, ascendente da família dos de Azevedo, viveu pelos meados do século XI. Casou com Maria Soares, que veio mais tarde a ser repudiada, como forma de escapar à inimizade entre a sua família e a de Soeiro Galindes, cuja mulher havia sido assassinada por um irmão de Godinho. Fundou o mosteiro de Vilar de Frades, junto a Barcelos, o que talvez aponte para a posse de alguma fortuna rapidamente dispersa entre os seus descendentes. Apropriou-se de uma fracção do mosteiro de S. Pedro de Este, em 1055, como resultado da insolvência de uma dívida contraída por Quindiverga Vimaranes, cuja nora, com o objectivo de a reaver, terá pago a Godinho a soma de quarenta soldos. Participou no julgamento de Palência, em 1059. Depois do repúdio da mulher, foi morto por Paio Guterres, dos da Silva, tendo este sido cego por vingança de Trutesendo Galindes, dos de Paiva, primo de Godinho. Seu filho, Paio Godins, casou com Goncinha Nunes, irmã de Soeiro Nunes «Velho», e foi pai, entre três outras filhas, de Nuno Pais «Vida» e Mem Pais «Bofinho», dois cavaleiros frequentemente documentados na corte de Henrique, Teresa e Afonso Henriques (José Mattoso, «Ricos-homens...», p. 66, 72, 88, 89 e 152$)$.

${ }^{61}$ DC 421 (1059.12.31): «Ordonio notuit» (= CDF 111, de 1059.12.31).

${ }^{62}$ DC 421 (1059.12.31): «Diagus trutusindiz confirma»; «Menendo diaz confirma»; «Gosendu araldiz confirma»; «Sancius conde confirma»; «Domino Poncius confirma»; «Gomes eychiguiz confirma»; «Menendo gonsalui confirma»; «Godino ueegas confirma» (=CDF 111, de 1059.12.31). 
pouco provável que tivesse desempenhado tais funções neste contexto. $\mathrm{O}$ seu nome é apenas citado na lista em que se enumeram os membros que tiveram assento na assembleia judicial, ao lado do de seu primo, Nuno Vasques ${ }^{63}$. A presença de Nuno na assembleia judicial deve, por conseguinte, ter resultado de uma solicitação das autoridades do reino ou dos seus representantes locais, o colégio triunviral dos infanções portucalenses. Não obstante, por esta altura, Nuno era ainda um agente colaborante da política régia em questões judiciais, ainda que ocupando uma posição secundária relativamente a Gomes Échigues, Mendo Gonçalves e Godinho Viegas, que, segundo tudo nos leva a crer, desempenharam um papel mais relevante na resolução do litígio.

Nestas circunstâncias, parece-nos que, pelos meados do século XI, as relações que Nuno mantinha com os infanções que actuavam no território de Entre-Douro-e-Minho, com o apoio de Fernando I, davam os primeiros indícios de alguma fragilidade. Nuno começava a ver-se envolvido numa série de acontecimentos de que os seus poderes acabariam por sair esvaziados, em benefício de figuras que, em teoria, deviam obediência ao conde, mas que, na prática, vinham a afastar-se da sua influência em diversas matérias, devido ao apoio que recebiam do rei. Foi assim que vários senhores de famílias em ascensão na hierarquia social da época, como os da Silva, os de Sousa, os da Maia, os de Azevedo e, muito especialmente, os de Riba Douro, com o apoio de uma dinastia à procura de novas fontes de legitimidade política, aproveitaram a situação de alguma instabilidade que marcou o estabelecimento de Fernando I no trono - e, mais tarde, os problemas levantados pela sua morte e a atribuição do governo do reino de Galiza e Portucale a Garcia II -, para se apropriar das prerrogativas de poder que, pelo menos nominalmente, ainda pertenciam a Nuno.

\section{O proprietário}

O património que Nuno Mendes adquiriu por herança do lado paterno da família condal portucalense, em especial de sua avó, Ilduara Mendes, e de sua tia, Gontrode Nunes, era constituído maioritariamente por pequenas fracções de terra situadas na região de Braga. Não há nenhum testemunho que nos permita

${ }^{63} \mathrm{Se}$ os dois primos integraram o colectivo de que resultou a sentença proferida pela assembleia judicial, era natural que tivessem confirmado o diploma outorgado a favor do mosteiro de Soalhães, tal como aconteceu com os restantes juízes. É pouco provável que Nuno e Nuno Vasques tenham discordado da sentença judicial, e, desta maneira, se tenham recusado a confirmar o disposto em norma. Mas não sabemos explicar ao certo por que razão ambos não figuram na lista dos respectivos confirmantes. 
dizer que Nuno tenha comprado terras, nem sequer na região onde a sua família era detentora de alguns interesses patrimoniais, o que não significa que tal facto não tenha acontecido. Face à documentação que chegou até nós, o que podemos afirmar é que o património que Nuno acumulou ao longo da sua vida parece ter resultado mais da transmissão das propriedades que estiveram na posse de sua avó e que foram posteriormente partilhadas com a sua tia, do que de estratégias concebidas de forma a aumentar e a rentabilizar o potencial económico de propriedades que pudessem eventualmente ter estado na sua posse.

Como se compreende, a inexistência de qualquer acto que nos fale das características do património de Nuno, tal como dos contornos dos procedimentos jurídicos mediante os quais se deu a alienação de algumas propriedades em seu benefício, impede-nos de efectuar qualquer análise da sua política de gestão económica. Os diplomas que nos falam da composição das suas riquezas são não só muito lacunares e parcelares, como, em praticamente todos os casos, posteriores à morte do conde, pelo que tendem apenas a referir a natureza do regime jurídico de posse e usufruto das fracções de terra em causa. Por se tratar de documentos outorgados a título póstumo, estes diplomas apenas o identificam como proprietário, especificando a natureza das propriedades, mas não nos dão qualquer indicação sobre as circunstâncias que envolveram a sua incorporação no património do conde. O quadro que se segue sintetiza as principais informações relativas a esta questão:

Quadro n. 2 - Composição do património fundiário de Nuno Mendes (séc. XI)

\begin{tabular}{|c|c|c|c|c|c|c|}
\hline \multirow{2}{*}{$\begin{array}{l}\text { Data do } \\
\text { diploma }\end{array}$} & \multirow{2}{*}{$\begin{array}{l}\text { Modalidade } \\
\text { jurídica de } \\
\text { aquisição }\end{array}$} & \multirow[t]{2}{*}{ Contratantes } & \multicolumn{2}{|c|}{$\begin{array}{c}\text { Características da } \\
\text { propriedade }\end{array}$} & \multirow[t]{2}{*}{ Localização } & \multirow[t]{2}{*}{ Fonte } \\
\hline & & & Tipo & Fracção & & \\
\hline 1071.02 .17 & (?) & (?) & $\begin{array}{l}\text { Herdade } \\
\text { na vila }\end{array}$ & $\begin{array}{l}1 / 2 \text { da vila, } \\
\text { inteira }\end{array}$ & $\begin{array}{c}\text { «Luvane» } \\
\text { (Olivão, conc. de } \\
\text { Vila Verde) }\end{array}$ & $\begin{array}{c}\text { LF } 253 \text { (= } \\
\text { Carriedo } \\
\text { Tejedo, } \\
2001, \mathrm{p} . \\
538-539, \\
\left.\text { n. }^{\circ} 145\right)\end{array}$ \\
\hline 1072.04 .06 & Doação & $\begin{array}{c}\text { [Gontrode } \\
\text { Nunes, tia } \\
\text { co-proprietária] }\end{array}$ & Vila & $1 / 2$ da vila & $\begin{array}{c}\text { «Nogaria» } \\
\text { (Nogueiró, conc. } \\
\text { de Braga) }\end{array}$ & $\begin{array}{c}\text { LF } 201 \\
\text { (cf. LF } \\
202 \text { e LF } \\
173)\end{array}$ \\
\hline 1102 & Doação & $\begin{array}{c}\text { [Gontrode } \\
\text { Nunes, tia } \\
\text { co-proprietária] }\end{array}$ & Vila & $\begin{array}{l}1 / 2 \text { da vila, } \\
\text { inteira }\end{array}$ & $\begin{array}{c}\text { «Barvudo» } \\
\text { (Barbudo, conc. } \\
\text { de Vila Verde) }\end{array}$ & $\begin{array}{c}\text { LF } 315 \text { e } \\
\quad 643\end{array}$ \\
\hline
\end{tabular}




\begin{tabular}{|c|c|c|c|c|c|c|}
\hline \multirow{2}{*}{$\begin{array}{l}\text { Data do } \\
\text { diploma }\end{array}$} & \multirow{2}{*}{$\begin{array}{l}\text { Modalidade } \\
\text { jurídica de } \\
\text { aquisição }\end{array}$} & \multirow[t]{2}{*}{ Contratantes } & \multicolumn{2}{|c|}{$\begin{array}{c}\text { Características da } \\
\text { propriedade }\end{array}$} & \multirow[t]{2}{*}{ Localização } & \multirow[t]{2}{*}{ Fonte } \\
\hline & & & Tipo & Fracção & & \\
\hline 1103.07 .27 & $(?)$ & (?) & $(?)$ & (?) & $\begin{array}{c}\text { «Sancta Tecla» } \\
\left(\text { St. }{ }^{\text {a }} \text { Tecla, conc. }\right. \\
\text { de Braga })\end{array}$ & LF 173 \\
\hline 1103.07 .27 & (?) & $(?)$ & $(?)$ & (?) & $\begin{array}{l}\text { «Datin» (Dadim, } \\
\text { conc. de Braga) }\end{array}$ & LF 173 \\
\hline 1103.07 .27 & $(?)$ & $(?)$ & $(?)$ & (?) & $\begin{array}{c}\text { «Cerqueta» } \\
\text { (Cerqueda, conc. } \\
\text { de Braga) }\end{array}$ & LF 173 \\
\hline 1103.07 .27 & $(?)$ & (?) & $(?)$ & \begin{tabular}{|c|}
$1 / 3$ dos \\
direitos de \\
padroado \\
sobre a igreja \\
de S. Miguel \\
\end{tabular} & $\begin{array}{c}\text { «Sancti } \\
\text { Michaelis } \\
\text { de Gualtar» } \\
\text { (Gualtar, conc. } \\
\text { de Braga) }\end{array}$ & LF 173 \\
\hline 1103.07 .27 & \begin{tabular}{|c|} 
Doação por \\
imposição de \\
pena relativa a \\
homicídio
\end{tabular} & $\begin{array}{c}\text { Guilhifonso } \\
\text { Alvites }\end{array}$ & $\begin{array}{c}\text { Herdades } \\
\text { na vila }\end{array}$ & $\begin{array}{c}1 / 2 \text { das } \\
\text { herdades }\end{array}$ & $\begin{array}{c}\text { «Barrios» } \\
\text { (Barros, conc. de } \\
\text { Braga })\end{array}$ & LF 173 \\
\hline 1132.09 .28 & $(?)$ & $(?)$ & $(?)$ & Inteira & \begin{tabular}{|c} 
«Varzena de \\
Burrial» (Várzea \\
de Beiral, conc. \\
de Ponte de \\
Lima)
\end{tabular} & $\begin{array}{c}\text { LF } 427 \\
\text { e } 755\end{array}$ \\
\hline
\end{tabular}

Dos cinco actos que nos falam do património de Nuno, quatro, datados de 6 de Abril de $1072^{64}, 1102^{65}, 27$ de Julho de $1103^{66}$ e 28 de Setembro de $1132^{67}$, se lhe referem, como proprietário, a título póstumo. Apenas o acto inaugural desta lista de escassos diplomas, com data de 17 de Fevereiro de $1071^{68}$, foi lavrado em vida e a pedido do próprio. Como se nota pela data dos últimos dois diplomas constantes do quadro, décadas após a sua derrota e morte na batalha de Pedroso, ainda se faziam sentir os ecos da presença de Nuno como proprietário nas regiões de Braga e Ponte de Lima, facto que, logicamente, deve ser analisado à luz da importância social das figuras que intervieram no acto de produção desses mesmos diplomas: por um lado, os seus familiares

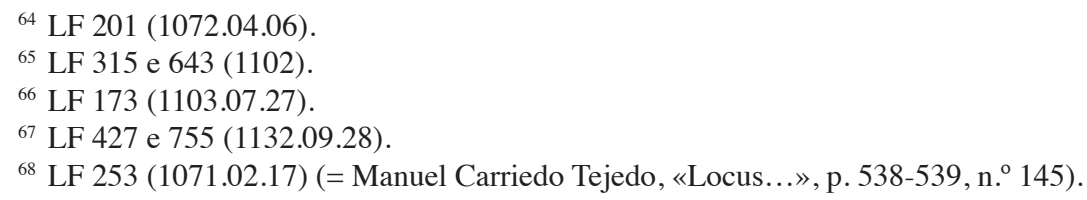


mais próximos, como Gontrode Nunes e o casal formado pela sua filha e genro, Loba Nunes e Sesnando Davides; e, por outro, Afonso Henriques.

Os bens que a documentação atribui a Nuno e que foram confiscados por ocasião da sua derrota e morte na batalha de Pedroso correspondem a um conjunto aparentemente homogéneo de propriedades fundiárias, situadas nos actuais concelhos de Vila Verde, Braga e Ponte de Lima. No terceiro quartel do século XI, contudo, distribuíam-se entre as vilas de Olivão, Nogueiró, Barbudo, St. ${ }^{a}$ Tecla, Dadim, Cerqueda, Gualtar, Barros e Várzea de Beiral, com uma dispersão territorial que ia do rio Lima ao rio Ave, ou seja, ocupando uma extensa área do condado de Portucale. As propriedades que Nuno possuía eram constituídas por fracções de terra concentradas maioritariamente na região de Braga, entre os rios Cávado e Este, a Leste da cidade, e, mais pontualmente, noutras áreas periféricas relativamente a este núcleo de concentração geográfica, como Ponte de Lima.

A área geográfica de dispersão das fracções de terra era, comparativamente à dos seus familiares, muito pequena. Pode dizer-se que se limitava praticamente ao vale do rio Cávado, embora com um ou outro casos mais pontuais de propriedades situadas um pouco mais a Norte, no vale do rio Lima. Esta situação parece ter decorrido da generalização da prática da partilha de heranças no seio da família condal portucalense, que, embora tivesse levado a uma fragmentação cada vez maior dos bens, acarretou também uma tendência para a divisão das heranças de acordo com a sua área de implantação geográfica ${ }^{69}$.

Entre os bens na posse de Nuno, os que mais se afastavam da área de concentração geográfica das propriedades herdadas de seus familiares - a região de Braga - eram os de Várzea de Beiral, na região de Ponte de Lima. Segundo o diploma que os refere, estes bens passaram para as mãos de Afonso Henriques algum tempo depois da morte de Nuno. Este, por sua vez, dispôs dos seus direitos de posse e usufruto desta vila a favor de Rodrigo Peres,

${ }^{69} \mathrm{O}$ caso mais significativo desse tipo de política de gestão do património parece ter ocorrido depois da morte de Hermenegildo Gonçalves, marido de Mumadona Dias, e da aplicação do disposto no respectivo instrumento de partilhas, datado de 24 de Julho de 950 (DC 61, de 950.07.24), mandado elaborar pelo conde em benefício de sua mulher e filhos, Gonçalo, Diogo, Ramiro, Ónega, Nuno e Ariano. Neste caso, o património na posse do conde foi dividido e legado aos seus familiares mais próximos como conjuntos orgânicos de bens, organizados segundo a respectiva área de concentração geográfica. É, no entanto, possível, na esteira do que afirmou A. de Almeida Fernandes («Portugal no período vimaranense (868-1128)» Revista de Guimarães, 81 (1971), p. 52), que os lugares indicados no instrumento de partilhas não totalizasse as possessões deixadas pelo conde. 
a 28 de Setembro de $1132^{70}$, vindo o destinatário a outorgar um ano depois, a 28 de Outubro de $1133^{71}$, uma carta de alienação dos direitos adquiridos, metade por doação, metade por venda, a favor da Sé de Braga. Os bens que pertenceram a Nuno foram, portanto, integrados no património da realeza portuguesa, provavelmente no quadro de uma herança resultante da política de confisco do património do conde adoptada pelo avô materno do doador, Afonso VI, depois da morte de Nuno, bem como da de seu rival, Garcia II, às mãos dos dois irmãos deste último, e, mais tarde, assimilados, por iniciativa do próprio rei, por um representante das mais altas famílias do reino, Rodrigo Peres.

\section{O cabecilha}

As circunstâncias da morte de Nuno são-nos dadas a conhecer pelos Anais de St. ${ }^{\circ}$ Tirso de Riba de Ave $e^{72}$, os primeiros de quatro anais redigidos num mosteiro do território de Entre-Minho-e-Mondego entre os finais do século XI e os finais do XII. Não sabemos exactamente os motivos que levaram o respectivo compilador a produzi-los, embora tal facto não se possa desligar das relações de padroado leigo que este mosteiro - formado por uma comunidade de monges observantes da Regra de S. Bento, protegida por uma família da nobreza regional de média estirpe rival dos condes de Portucale - mantinha com os senhores da Maia, aí representados por três gerações de infanções: Gonçalo Trastamires, Mendo Gonçalves e Soeiro Mendes. Sabemos, contudo, que a sua redacção deve ter ocorrido por volta de 1079, isto é, na altura em que se assistia aos inícios da progressão militar da monarquia leonesa no território de Entre-Minho-e-Mondego, de que resultaram, entre outras, as conquistas de Seia, em 1055, Lamego, em 1057, Viseu, em 1058, e Coimbra, em 1064.

Estes anais conservaram-se até nós, sob a forma de cópia, no Livro da Noa $\mathrm{II}^{73}$ - um texto transmitido num livro litúrgico contendo as horas canónicas de Noa, contendo uma miscelânea de notícias escritas, em várias épocas, nos três cadernos finais de um Saltério de horas diurnas, compiladas entre 1362 e 1365 e na Chronica Gothorum ${ }^{74}$ - um texto resumido na compilação designada como Breuis chronica Gothorum ou Breuis historia Gothorum, um resumo efectuado

${ }^{70}$ LF 427 e 755 (1132.09.28) (cf. apênd. 1, n. ${ }^{\circ}$ 1.9).

${ }^{71}$ LF 426 (1133.10.28).

${ }^{72}$ Mário de Gouveia, «O essencial sobre a analística monástica portucalense (séc. XI-XII)», Lusitania sacra. Revista do Centro de Estudos de História Religiosa, 2. a série, t. XXV, Janeiro-Junho de 2012, p. 199-201.

${ }^{73}$ Mário de Gouveia, «O essencial...», p. 192-193, n. ${ }^{\circ} 3.4$.

${ }^{74}$ Mário de Gouveia, «O essencial...», p. 193, n. ${ }^{\circ} 3.6$. 
por Gaspar Álvares de Lousada Machado, secretário do arcebispo de Braga, Fr.Agostinho de Jesus, no século XVII -, contendo um total de dezoito notícias, na primeira versão, e de vinte, na segunda. O seu relato cobre o período que vai de 987 a 1079, representado narrativamente pela conquista de Coimbra por Muḥammad ibn Ab̄̄ 'Āmīr al-Manșūr, ḥājib de Córdova no governo do am̄̄r al-mu 'minīn omíada Hishām II al-Mu'ayyad e pela ocorrência de um eclipse solar total sucedâneo da conquista de Cória por Afonso VI.

Entre as várias perícopes que aí se encontram referentes aos condes de Portucale - como Mendo [Gonçalves] ${ }^{75}$, filho de Gonçalo Mendes e Ilduara Pais; Alvito Nunes ${ }^{76}$, filho de Nuno Alvites e de uma senhora cujo nome se desconhece; Nuno Alvites ${ }^{77}$, filho de Alvito Nunes e Goncinha; e Mendo [Lucides], filho de Lucídio Alvites e Ximena, ou Mendo [Nunes] $]^{78}$, filho de Nuno Alvites e Ilduara Mendes, geralmente citados a propósito de acontecimentos em que estes são derrotados em batalha ou mortos de forma ignominiosa -, encontra-se uma relativa a Nuno, incorrectamente datada do décimo quinto dia das calendas de Fevereiro da era de 1109, ou seja, de 18 de Janeiro de $1071^{79}$.

${ }^{75}$ AST, era de 1046 (ano de 1008): «Era 1046, $2^{\circ}$ nonas octobris occisus fuit comes Menendus.» (APV, Recensão longa de 1079, secção III, seg. Chronica Gothorum: ed. Pierre David, Lisboa-Paris, 1947, p. 295). José Mattoso, «As famílias...», p. 106-107, ref. a IV.B.

${ }^{76}$ AST, era de 1054 (ano de 1016): «Era 1054, $8^{\circ}$ idus septembris veniunt Lormanes ad Castellum Vermudii quod est in prouincia Bracharensi; comes tunc ibi erat Aluitus Nuniz.» (APV, Recensão longa de 1079, secção III, seg. Chronica Gothorum: ed. Pierre David, Lisboa-Paris, 1947, p. 295). José Mattoso, «As famílias...», p. 83-84, ref. . I.E.

77 AST, era de 1056 (ano de 1018): «Et in ipso anno [era 1056] obiit magnus comes Nunus Aluitis» (APV, Recensão longa de 1079, secção III, seg. Chronica Gothorum: ed. Pierre David, Lisboa-Paris, 1947,p. 295). A data correcta da ementa é [1028]. José Mattoso, «As famílias...», p. 84 , ref. ${ }^{\text {a I.F. }}$

${ }^{78}$ AST, era de 1072 (ano de 1034): «Era $M^{\mathrm{a}} \mathrm{LXX}^{\mathrm{a}} \mathrm{II}^{\mathrm{a}}$ occisus fuit comes Menendus in ripa Guetanie VIIII ${ }^{\circ}$ kalendas ianuarias.» (APV, Recensão longa de 1079, secção III, seg. Chronica Gothorum: ed. Pierre David, Lisboa-Paris, 1947, p. 295). A data correcta da ementa é [1044]. José Mattoso, «As famílias...», p. 82 e 85-86, ref..$^{\text {as }}$ I.C.2 e I.G, respectivamente.

$79 \mathrm{Tal}$ como afirmámos anteriormente, poderíamos considerar a data transmitida nesta perícope analística como verdadeira, caso não subsistissem outros testemunhos sobre a acção de Nuno atribuídos a um período posterior ao que os anais identificam como sendo o da sua morte. Com efeito, conservou-se até nós um diploma pelo qual Nuno, juntamente com a sua mulher, Goncinha, doou todos os seus bens ao mosteiro de Barbudo. A data patente neste diploma, o décimo terceiro dia das calendas de Março da era de 1109, ou seja, 17 de Fevereiro de 1071, assinala o acto de outorga do diploma ao respectivo destinatário. Se, nessa altura, Nuno surge na qualidade de outorgante de uma doação, tal facto só poderá querer indicar que uma das duas datas - a analística, por um lado (18 de Janeiro), ou a diplomática, por outro (17 de Fevereiro) - estará incorrecta. Ainda que haja consonância de informações quanto ao ano em que tiveram lugar a doação a Barbudo e a batalha de Pedroso, o mesmo não se poderá dizer quanto ao mês e 


\section{Nesta perícope, o analista diz-nos textualmente: «Na era de 1109, no décimo quinto dia das calendas de Fevereiro, os Portucalenses travaram uma batalha}

dia de ocorrência dos dois acontecimentos. Uma vez que os anais colocam a morte de Nuno em data anterior à que este teria feito a sua doação, podemos dizer que uma ou até mesmo ambas as fontes não conservam informações correctas quanto à data das duas efemérides. Esta questão pode ser melhor equacionada se tivermos em mente que os diplomas reunidos no Liber fidei, mormente quando representando conjuntos orgânicos de cartas aí incorporadas em diversos momentos da elaboração do códice diplomático, seguem uma ordem cronológica sequencial mais ou menos precisa. Pelo menos assim acontece com o conjunto dos diplomas que compõem o arquivo do mosteiro de Barbudo, reunidos no códice por ordem cronológica. Se partirmos desse pressuposto, que estabelece um ponto de apoio para a crítica da data patente nos Anais de St. ${ }^{\circ}$ Tirso de Riba de Ave, somos obrigados a considerar como válida a data patente no diploma, até por este ter sido transcrito num fólio do códice logo depois de um diploma datado de 30 de Outubro de 1070 (LF 252, de 1070.10.30). Por outro lado, Nuno não estaria vivo em 1072, pelo que a data patente neste registo deve considerar-se fidedigna. Se o diploma pode, de facto, datar-se de 17 de Fevereiro de 1071, tal facto levanta-nos à partida duas questões: ou a batalha de Pedroso foi travada depois desse dia; ou Nuno, tal como referem os anais, não morreu em combate. A afirmação unânime dos diversos manuscritos que transmitem o texto analístico segundo a qual Nuno morreu em combate parece não suscitar dúvidas quanto à interpretação dos factos: Nuno pereceu nos campos de Pedroso e os seus apoiantes dispersaram-se após a sua morte. O mesmo não pode dizer-se da data patente nesses manuscritos, que, na Chronica Gothorum, é identificada com o dia 18 de Janeiro de 1071, e, no Manuscrito de Lousada, é atribuída a dia incógnito do mês de Fevereiro de 1071. Na prática, ao contrário do registado na Chronica Gothorum, este último testemunho vem ao encontro da data proposta pelo diploma, faltando apenas a indicação exacta do dia em que se travou a batalha. Podemos, portanto, aceitar como verdadeira a data patente no diploma, e, assim sendo, situar numa data compreendida entre [18] e [28] de Fevereiro de 1071 o dia em que se travou a batalha. A corroborar-se este facto, tenha-se presente que é no Manuscrito de Lousada, que aparentemente se baseou num texto mais correcto do que o transmitido pela Chronica Gothorum, que se encontra a data correcta da morte do rei Afonso V e do conde Nuno Alvites, que sabemos ter ocorrido em 1028, para além da grafia regularizada do topónimo indicativo do local onde se travou a batalha. Com base nestes aspectos, podemos não só situar o combate nos finais do mês de Fevereiro, como inclusive ter por certa a informação que nos diz que Nuno morreu durante o confronto. Sabemos ainda que, no ano de 1071, os dias 20 e 27 de Fevereiro coincidiram com um Domingo. Na religiosidade do tempo, que valorizava este dia da semana como momento da solene celebração do mistério pascal, relacionado com a Crucifixão e a Ressurreição do Senhor um Domingo depois da Sua triunfal entrada em Jerusalém, esta coincidência obrigaria a que se evitasse qualquer forma de confronto, mormente se implicasse potencial derramamento de sangue de homens considerados como figuras especialmente protegidas e abençoadas por Deus, como era o caso dos reis. Nestas circunstâncias, podemos talvez afastar estes dois dias como datas de ocorrência do confronto, e, nesta linha de pensamento, limitar as nossas hipóteses quanto à data de ocorrência do acontecimento. Tendo em conta as informações disponíveis, indirectamente conservadas através das cronologias analística e diplomática, é, pois, possível que a batalha tenha tido lugar algures entre os dias [18] e [19], [21] a [26], ou ainda [28] de Fevereiro de 1071. Em última instância, a outorga da carta de doação ao mosteiro de Barbudo, ocorrida a 17, obrigar-nos-ia a aproximar a batalha de uma das datas iniciais deste intervalo de tempo. Sobre os problemas levantados pela cronologia do diploma, veja-se LF, vol. I, p. 334-336, nota 1. 
contra o rei D. Garcia, filho do rei D. Fernando, tendo então por cabecilha nessa mesma batalha o conde Nuno Mendes. Este morreu aí, e todos os seus fugiram juntos. O rei alcançou vitória sobre eles no lugar que se diz de Pedroso, entre Braga e o rio Cávado» ${ }^{80}$.

A 1 Fevereiro de $1071^{81}$, vésperas da festa litúrgica da Purificação de Nossa Senhora $^{82}$, Garcia II doou ao bispo Jorge de Tui uma propriedade situada no lugar de Vilar de Mouros, com todos os seus termos e edifícios, entre os quais uma igreja consagrada à mártir St. ${ }^{a}$ Eulália, bem como uns casais em Seixas, situado na vertente Sul do estuário do rio Minho. A doação tinha como objectivo garantir o cumprimento da vontade do rei, que visava a redenção da sua alma, tal como da de seus pais, Fernando I e Sancha, os quais haviam adquirido e transmitido esses bens ao filho, junto com os homens que neles trabalhavam ${ }^{83}$.

${ }^{80}$ APV, secção III, seg. Chronica Gothorum: «Era 1109, $15^{\circ}$ calendas februarii Portugalenses commiserunt prelium aduersus regem Domnum Garsiam filium regis Domni Fernandi, habebantque tunc caput in ipso bello comitem Nuno Menendiz; periit ipse ibi et cuncti alii sui fugerunt; obtinuit autem rex de illis uictoriam in loco qui dicitur Petrosum inter Bracharam et fluvium Cavado.» (ed. Pierre David, Lisboa-Paris, 1947, p. 298).

${ }^{81}$ DC 494 (1071.02.01) (= Manuel Carriedo Tejedo, «Locus...», p. 538, n. ${ }^{\circ} 144=$ Ermelindo Portela Silva, García II..., apênd. A, n. ${ }^{\circ} 7$ = Ernesto Iglesias Almeida, $O$ bispado de Tui en Portugal, Noia, Editorial Toxosoutos, 2008, apênd., doc. 1 [em tradução parcial]). Ernesto Iglesias Almeida, O bispado..., p. 33.

${ }^{82}$ Le calendrier de Cordoue (Publié par R. Dozy; nouvelle édition accompagnée d'une traduction française annotée par Ch. Pellat), Leiden, E. J. Brill, 1961, p. 39 (Calendário de Córdova [961; seg. tradução latina]: «Dies in eo est decem horarum et tertie, et nox est ex tredecim horis et duabus terciis. Et occidit in eo crepusculum vespertinum quando preterit de nocte hora et quinta. Et oritur crepusculum matutinum quando remanet de nocte equale ei.»); José Vives e Ángel Fábrega, «Calendarios hispánicos anteriores al siglo XII», Hispania sacra. Revista de historia eclesiástica, vol. II, n. ${ }^{\circ} 3$, fasc. $1 .^{\circ}$, Janeiro-Junho de MCMXLIX (1. ${ }^{\circ}$ semestre), p. 124 (Calendário de Ripoll [séculos X-XI]: «KL. FBR. Sce. Brigide uirg.») e 141 (Calendários vigilano [976] e emilianense [994]: sem ref.a); «Calendarios...», vol. II, n. ${ }^{\circ} 4$, fasc. $2{ }^{\circ}$, Julho-Dezembro de MCMXLIX (2. ${ }^{\circ}$ semestre), p. 350 (Calendário silense I [1039]: sem ref.a), 356 (Calendário silense II [1052]: sem ref.a), 362 (Calendário compostelano [1055]: sem ref. ${ }^{\text {) }}$, 368 (Calendário leonês [1067]: sem ref. ${ }^{\text {a) }}$ e 374 (Calendários silenses de Paris [1067]: sem ref.a); José Janini, «Dos calendarios emilianenses del siglo XI», Hispania sacra, vol. XV, n. ${ }^{\circ}$ 29, MCMLXII (1. ${ }^{\circ}$ semestre), p. 179 (Calendário emilianense [século XI]: sem ref.a). Cf. festas da liturgia romana, a partir de calendários hispânicos dos séculos XI, XII e XIII, em José Janini, «Dos calendarios...», p. 184 (Calendário emilianense [século XI]: a 1 de Fevereiro, «Brigide urg.»); L. López Santos, «Calendarios litúrgicos leoneses», Archivos leoneses. Revista del Centro de Estudios e Investigación de «San Isidoro», ano X, n. ${ }^{\circ}$ 19, Janeiro-Julho de 1956, p. 126 (Calendários leoneses [séculos XII-XIII]: a 1 de Fevereiro, sem ref.a).

${ }^{83}$ Ermelindo Portela Silva, García II..., p. 77-80. O documento que nos remete para esta doação é um apógrafo autêntico elaborado no século XIV, copiado várias centúrias mais tarde, no decurso do século XVIII, e posteriormente depositado na biblioteca da Academia das Ciências 
Segundo uma das cláusulas finais do diploma, Garcia II procurava constituir uma fonte de receitas ao dispor de todos aqueles que se entregavam ao serviço de Deus e da Igreja, à medida em que reclamava para si a misericórdia do Senhor no dia do Juízo Final. Antes de assinar o documento, considerou necessário sublinhar que todos os bens doados constituíssem, a partir de então, um património inalienável, visto que, uma vez transferidos os respectivos direitos de posse e usufruto a favor da Sé de Tui, ninguém deveria ir contra o disposto em norma. As penas que decorrerriam da quebra deste interdito passavam pela excomunhão e a maldição do infractor, condenado a morrer como Datan e Abiron, que se revoltaram contra Moisés e foram engolidos vivos pela terra, e a sofrer as penas do Inferno ao lado de Judas Iscariotes, o traidor de Jesus Cristo. Ao mesmo tempo, determinava-se a obrigatoriedade de o infractor entregar àquela Sé dois talentos de ouro para remissão dos seus pecados, caso violasse a vontade expressa do doador.

O tom solene que caracteriza este diploma ${ }^{84}$, reflexo da condição social privilegiada das figuras que intervieram na sua elaboração, traduz-se num discurso muito apelativo em imagens, patente na nomeação de Garcia II como o «exíguo e inútil rei por vontade de Deus» («Ego exiguus, et inutilis Garcia Dei nutu Rex») ou ainda como o «sereníssimo príncipe e rei por vontade de Deus» («Ego serenissimus Princeps Garcia nutu Dei Rex»); tal como de Jorge, como o «magno pontífice e bispo por graça de Deus» («vobis Pontifici Magno Georgio gratia Dei Episcopo»). O cuidado posto na invocação da Santíssima Trindade e de todas as instâncias celestes cujas memórias eram especialmente cultuadas naquela Sé, parece reflectir a mesma retórica solenizante, de forma a conferir um carácter excepcional à doação como único instrumento de mediação possível entre os mundos visível e invisível. De resto, sublinhe-se que também a lista dos seus subscritores, entre confirmantes e testemunhas, parece

de Lisboa, onde Alexandre Herculano, o seu primeiro editor, o terá visto, analisado e publicado. A outorga do documento antecedeu em poucos dias a batalha de Pedroso, travada nos finais do mês de Fevereiro. Embora não descrevendo em pormenor a composição da vila doada pelo rei galego ao bispo tudense, nele se procede à identificação dos respectivos termos com base na existência de montes e vilas, da mesma forma que se dá conta da presença de algumas casas e salinas igualmente doadas pelo rei galego à Sé de Tui.

${ }^{84}$ Ermelindo Portela Silva, García II..., p. 97-98. Este historiador estudou detalhadamente este diploma, chegando à conclusão de que o tom pessimista do formulário nele utilizado reflectia o ânimo do rei e a instabilidade que dominava a sua acção governativa nos inícios da década de setenta do século XI. Ainda segundo este historiador, o exórdio do privilégio da Sé de Tui não seria mais do que um sintoma da inquietação do rei perante as circunstâncias que precederam a batalha de Pedroso, e, nessa qualidade, expressão de um mau presságio relativamente ao destino incerto que pairava sobre a sua governação. 
corroborar esta hipótese: à sua cabeça surge apenas o nome do rei, e, logo a seguir, os de vários religiosos, entre abades e um confessor, e os de vários leigos. Entre aqueles, identifica-se facilmente o nome de Rando ${ }^{85}$, abade do mosteiro de St. ${ }^{\circ}$ Antonino de Barbudo, e, entre estes, o de Nuno Soares ${ }^{86}$, dos de Grijó. Estão ausentes os nomes dos homens que estiveram ao lado de Garcia II nos anos anteriores, quando este outorgou em benefício dos de Riba Douro cartas de doação que ampliaram consideravelmente o seu património. Também o nome de Nuno não se encontra na lista.

É bem possível que esta doação à Sé de Tui, que se revestiu de um carácter solene e contou com a participação de numerosos religiosos e leigos, traduzisse da parte do rei uma série de preocupações relativamente à situação de instabilidade política que se vivia no reino, de que a batalha de Pedroso acabaria por ser apenas uma manifestação. Há um contraste muito significativo entre a tonalidade discursiva dos primeiros diplomas outorgados por Garcia II e a que domina os diplomas que foram lavrados pouco antes de o rei ser capturado e aprisionado pelos seus irmãos no castelo de Luna. Frente ao optimismo do juramento com que havia iniciado o seu reinado, mediante o qual se tornara possível criar uma rede de apoios de que faziam parte o bispo Vistruário de Lugo e os condes Mido e Sancho, fonte de amparo e protecção, e face às expectativas criadas pelo reforço destes laços de apoio mútuo, na sequência das doações régias ao mosteiro de St. ${ }^{\circ}$ Antonino de Toques, a 23 de Fevereiro de $1067^{87}$, tal como aos leigos Múnio Viegas e Afonso Ramires, dos de Riba Douro, em $1068^{88}$ e a 16 de Maio (?) de $1070^{89}$, respectivamente - nas quais se sublinharam as boas relações que estes tinham com o rei, pelo «bom serviço» («seruitium bonum») e a «verdade recta» («ueritatem directam») que lhe haviam feito e dito, e se falou da necessidade de se recompensar essa lealdade numa duradoura aliança entre o rei e os infanções -, do formulário retórico do privilégio da Sé de Tui transparece, ao invés, a consciência pessimista do rei relativamente ao momento presente, apenas ultrapassável através do

${ }^{85}$ DC 494 (1071.02.01) (= Manuel Carriedo Tejedo, «Locus...», p. 538, n. ${ }^{\circ} 144=$ Ermelindo Portela Silva, García II..., apênd. A, n. ${ }^{\circ} 7$ = Ernesto Iglesias Almeida, O bispado..., apênd., doc. 1 [em tradução parcial]): «Rando Abbas conf. +».

${ }^{86}$ DC 494 (1071.02.01) (= Manuel Carriedo Tejedo, «Locus...», p. 538, n. ${ }^{\circ} 144=$ Ermelindo Portela Silva, García II..., apênd. A, n. ${ }^{\circ} 7$ = Ernesto Iglesias Almeida, O bispado..., apênd., doc. 1 [em tradução parcial]): «Nuno Suariz conf.».

${ }^{87}$ Ermelindo Portela Silva, García II..., apênd. A, n. ${ }^{\circ} 4$ (1067.02.23).

${ }^{88}$ DC 474 (1068.[...].4 ou 6) (= Ermelindo Portela Silva, García II..., apênd. A, n. ${ }^{\circ}$ 5).

${ }^{89}$ DC 491 (1070.05?.16) (= Manuel Carriedo Tejedo, «Locus...», p. 536, n. ${ }^{\circ} 139=$ Ermelindo Portela Silva, García II..., apênd. A, n. ${ }^{\circ}$ 6). 
sentido penitencial da existência humana. O que se invoca não é mais a ideia de lealdade e compromisso que transparecia dos actos outorgados no início do seu reinado. Poucos dias antes da batalha, o estado de ânimo em que o rei se encontrava tê-lo-ia obrigado a adoptar uma atitude mais cautelosa em relação aos seus súbditos, motivando a necessidade de se socorrer dos servos de Deus e da misericórdia do Senhor como única solução possível para a crise em que o reino se encontrava, em grande medida decorrente do enfraquecimento das suas relações com alguns dos seus subordinados políticos.

A análise do diploma de doação à Sé de Tui, o último acto público em que Garcia II se viu envolvido poucos dias antes de travar a batalha, permite-nos, pois, pensar que o rei ainda estivesse nesta cidade, levantada sobre um outeiro que dominava a bacia do rio Minho, antes de descer com os seus exércitos em direcção a Braga, cruzando o rio Cávado e encontrando-se com os exércitos de Nuno no lugar de Pedroso. A doação que havia efectuado a favor da Sé de Tui garantia-lhe o apoio espiritual de que necessitava junto de Deus e dos Seus santos para a salvação da sua alma. A tensão que pairava no ar estava prestes a dar origem ao seu primeiro confronto armado, do qual, a breve trecho, ambas as partes acabariam por sair derrotadas.

Como é evidente, também Nuno deve ter aproveitado esta situação de instabilidade para tentar fazer vingar os seus interesses. Não teria ousado revoltar-se contra um rei tão poderoso como Fernando I, esperando antes por uma ocasião mais propícia para reivindicar os seus privilégios perdidos. A morte do rei e a ascensão de seu filho mais novo ao poder, à frente de um reino sem o potencial militar do dos vizinhos reinos de Leão e de Castela, deve ter constituído um momento oportuno para o conde reclamar esses direitos. As circunstâncias pareciam jogar a seu favor.

Não sabemos quem comandou os exércitos régios durante a batalha. Ainda que tenhamos notícia de que Garcia II era coadjuvado nestas funções por figuras da sua mais alta confiança política, como Rodrigo [Moniz] ou [Garcês], presente a 24 de Março de $1066^{90}$ na cerimónia pública de confirmação do instrumento jurídico mediante o qual Garcia Moniz e sua mulher, Elvira, doaram ao rei várias herdades localizadas no território de Entre-Douro-e-Minho, é possível que tal função estivesse ainda nos inícios de 1071 nas mãos da única figura que sabemos ter desempenhado esse papel poucos meses antes do recontro: Soeiro Segeredes, o primeiro subscritor, na qualidade de confirmante,

${ }^{90}$ DC 451 (1066.03.24) (= Manuel Carriedo Tejedo, «Locus...», p. 523, n. ${ }^{\circ} 116=$ Ermelindo Portela Silva, García II..., apênd. A, n. ${ }^{\circ}$ 3). 
da doação de Garcia II a Afonso Ramires, datada de 16 de Maio (?) de $1070^{91}$, então com o título de «alferes do rei» («armiger regis»). No caso dos exércitos condais, a perícope analística é clara: os Portucalenses estavam sob a chefia de Nuno («habebantque tunc caput in ipso bello comitem Nuno Menendiz»). Não sabemos, contudo, quem eram os Portucalenses a que se refere o analista.

Tal como o seu rival, o conde preparou-se para o confronto armado. Procurando a salvação da sua alma, dirigiu-se com a mulher, Goncinha, ao mosteiro de Barbudo, e, a 17 de Fevereiro de $1071^{92}$, dezasseis dias depois da concessão do privilégio à Sé de Tui - data em que a Igreja não comemorava nenhuma festa litúrgica associada a um santo específico ${ }^{93}$ - fez uma doação à comunidade monástica contemplando uma herdade própria situada em Olivão, junto a Braga. Nessa altura, Nuno parecia demonstrar inquietações semelhantes às que, poucos dias antes, tinham levado Garcia II a refugiar-se sob a protecção espiritual da Sé de Tui.

A carta em que Nuno determinou fosse salvaguardada a sua última vontade recebeu no códice diplomático para o qual foi posteriormente transcrita o nome de «Testamento feito por Nuno Mendes a S. Bartolomeu de Brito, na vila de Olivão» («Tes[tamen]tum quod concessit Nunnus Menendiz S[an $] \mathrm{c}[t]$ o Bartolomeo de Brito in villa Luvane»). O título com que ficou conhecida identifica a natureza do registo jurídico, bem como o nome das partes implicadas no acto: por um lado, o doador, Nuno, mencionado com base no seu nome próprio e patronímico, embora sem referência à sua condição de conde; e, por outro, a instituição donatária, o mosteiro de S. Bartolomeu de Brito, ou seja, St. ${ }^{\circ}$ Antonino de Barbudo. Paralelamente, as cláusulas diplomáticas localizam

${ }^{91}$ DC 491 (1070.05?.16) (= Manuel Carriedo Tejedo, «Locus...»,p. 536, n. ${ }^{\circ} 139=$ Ermelindo Portela Silva, García II..., apênd. A, n. ${ }^{\circ}$ 6; cf. apênd. 1, n. ${ }^{\circ}$ 1.3).

${ }^{92}$ LF 253 (1071.02.17). Sobre a história deste mosteiro no século XI, leia-se Maria Helena da Cruz Coelho, «Santo Antonino de Barbudo - Um protagonista monástico da região bracarense em tempos medievos», in Homens, espaços e poderes (séculos XI-XVI), II: Domínio senhorial, Lisboa, Livros Horizonte, 1990, p. 7-29.

${ }^{93}$ Le calendrier..., p. 45 (Calendário de Córdova [961; seg. tradução latina]: sem ref.a); José Vives e Ángel Fábrega, «Calendarios...», vol. II, n. ${ }^{\circ}$ 3, fasc. 1. ${ }^{\circ}$, p. 124 (Calendário de Ripoll [séculos X-XI]: sem ref.a) e 141 (Calendários vigilano [976] e emilianense [994]: sem ref. ${ }^{\text {a) }}$; «Calendarios...», vol. II, n. ${ }^{\circ} 4$, fasc..$^{\circ}$, p. 350 (Calendário silense I [1039]: sem ref..$^{a}$ ), 356 (Calendário silense II [1052]: sem ref.a), 362 (Calendário compostelano [1055]: sem ref.a), 368 (Calendário leonês [1067]: sem ref.a) e 374 (Calendário silense de Paris [1067]: sem ref.a); José Janini, «Dos calendarios...», p. 179 (sem ref.a). Cf. festas da liturgia romana, a partir de calendários hispânicos dos séculos XI, XII e XIII, em José Janini, «Dos calendarios...», p. 184 (Calendário emilianense [século XI]: a 17 de Fevereiro, sem ref.a); L. López Santos, «Calendarios...»,p. 126 (Calendários leoneses [séculos XII-XIII]: a 17 de Fevereiro, sem ref.a). 
os bens doados à instituição no lugar de Olivão e indicam a natureza dos bens alienados por Nuno: uma herdade na vila. Ao proceder à doação, cujo diploma foi conservado no fundo monástico até ao momento em que a instituição integrou o padroado da Sé de Braga, tendo então sido copiado para o Liber fidei, Nuno determinou fosse criteriosamente definido o termo da sua propriedade e deu ordens no sentido de que não deixasse de ser aí mencionado o facto de a sua fracção de terra confrontar com outras então na posse das igrejas de S. Paio de Moure e de S. Julião da Laje, situadas a Sudoeste do mosteiro, cujos direitos de posse importava, de igual forma, salvaguardar.

O diploma foi anotado por Maurelo ${ }^{94}$, figura que não se identifica como um religioso, mas que podemos identificar com um homónimo que surge com relativa frequência nos diplomas produzidos no mosteiro de Barbudo. Tratar-se-ia, sem dúvida, de alguém ligado à comunidade monástica. Uma vez elaborado, o diploma foi assinado por várias figuras, entre testemunhas e confirmantes: para além dos nomes de Nuno e Goncinha ${ }^{95}$, identificados sem os respectivos patronímicos, mas surgindo na qualidade de condes, nele se encontram os nomes de Gontrode Nunes e Nuno Vasques, para além dos de Estêvão, Gondesendo, Lúcio Peres, Bermudo Lovesendes e Aldreto Eriz ${ }^{96}$, de difícil identificação. No último acto público a preceder a batalha de Pedroso, estiveram, pois, presentes a sua mulher, a sua tia paterna e o seu primo. Ausentes, os meirinhos de Garcia II e os infanções com os quais Nuno havia colaborado como agente judicial décadas antes. Na prática, os senhores que constituíam o principal círculo de apoio político do rei no território de Entre-Douro-e-Minho.

$\mathrm{O}$ encontro entre as forças militares chefiadas pelo conde e o rei deu-se numa zona que, apesar da sua proximidade a Braga, um dos mais importantes núcleos urbanos do Noroeste hispânico, constituía seguramente um ermo nos inícios da década de setenta do século XI. Pelo menos é neste sentido que parece apontar a notória falta de informações acerca da existência de unidades de povoamento rural na região na documentação que chegou até nós. Este lugar, que os Anais de St. ${ }^{o}$ Tirso de Riba de Ave situam entre Braga e o rio Cávado, correspondia a uma zona periférica da cidade, apresentando provavelmente características de um amplo descampado apenas atravessado pela estrada romana que partia

${ }^{94}$ LF 253 (1071.02.17): «Maurelus notuit.».

${ }^{95}$ LF 253 (1071.02.17): «Nunnus comes et Goncina comitissa hoc testamentum manibus nostris roboramus.».

${ }^{96}$ LF 253 (1071.02.17): «Gontrode devota conf.»; «Nunnus Velasquiz conf.»; «Stephanus ts.»; «Gundesindus conf.»; «Luzu Petriz conf.»; «Vermudus Lovendiz ts.»; «Aldreto Eriz conf.». 
da cidade na direcção de outros aglomerados populacionais da Galiza, entre os quais Tui, junto ao litoral atlântico.

O facto de Garcia II e Nuno terem efectuado duas importantes doações à Sé de Tui e ao mosteiro de Barbudo poucos dias antes de se encontrarem em Pedroso, nas quais não deixaram de solicitar aos religiosos que rezassem pelas suas almas e intercedessem por si diante da Providência divina, parece sugerir que a batalha não foi um encontro casual, mas antes a expressão de um confronto latente preparado por ambas as partes. É até possível, tendo em conta a geografia do confronto, que Nuno tenha sido surpreendido pelo avanço dos exércitos de Garcia II, que, vindos provavelmente da região de Tui, devem ter seguido a estrada romana que ligava esta cidade a Braga e ultrapassado os cursos dos rios Lima, Minho e Cávado, seguindo em direcção à região onde o conde seguramente se encontrava.

Mas, como se compreende, é difícil reconstituir o itinerário percorrido pelas forças galegas na sua deslocação ao território portucalense. Podemos pensar na hipótese de os exércitos terem feito esse percurso através da rede viária romana que ligava aquelas duas cidades ${ }^{97}$. Mas nada nos permite afirmá-lo com segurança. Trata-se apenas de uma hipótese que se mostra plausível à luz das fontes da época. Não temos, pois, forma de saber se Garcia II conduziu as suas forças até à margem esquerda do rio Cávado, onde se daria o confronto, com o objectivo de se aproximar de Braga e tomar a cidade, vindo a encontrar nas suas imediações as forças lideradas por Nuno, ou se, ao invés, procurou dirigir-se à região apenas com o objectivo de sufocar uma revolta cujo epicentro seria este núcleo urbano, regressando depois à sua terra de origem. Tudo o que sabemos é que, como resultado do recontro, Nuno morreu durante a batalha e os seus partidários acabaram por fugir frente aos exércitos de Garcia II, que reclamaram vitória.

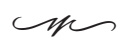

Após a derrota e morte de Nuno Mendes na batalha de Pedroso, mais ninguém reivindicou o direito a utilizar o título de conde de Portucale. Os seus herdeiros naturais eram Loba Nunes e Sesnando Davides, filha e genro do conde morto em combate. À luz da tradição da família, recaía sobre estas duas figuras, seus parentes mais próximos, o direito a utilizar o título que exprimia

\footnotetext{
${ }^{97}$ Antonio Rodríguez Colmenero, Santiago Ferrer Sierra e Rubén D. Álvarez Asorey, Miliarios e outras inscricións viarias romanas do Noroeste hispánico (conventos bracarense, lucense e asturicense), Santiago de Compostela, Consello de Cultura Galega/Sección de Patrimonio Histórico, 2004.
} 
a condição de representante da autoridade régia leonesa no território de Entre-Douro-e-Minho. Mas tudo parece indicar que Loba e Sesnando adoptaram uma postura muito discreta na crise que se seguiu à batalha. $\mathrm{O}$ casal limitou-se a receber das mãos de Afonso VI alguns dos bens que haviam pertencido a Nuno, e que, depois da sua derrota, foram confiscados por Garcia II e apropriados pelo irmão mais velho, depois de Garcia II ter sido feito prisioneiro no castelo de Luna, no quadro das rivalidades que o opuseram a Afonso VI e Sancho II.

Não sabemos ao certo em que momento se deu a entrega destes bens, embora possamos situá-la num espaço de cerca de três anos após a morte de Nuno, entre o confisco do património por Garcia II, em 1071, e a doação de parte de Nogueiró a um casal de leigos, em 1074. O que parece seguro é que o gesto de Afonso VI fez com que regressasse temporariamente à família do conde o património que este havia herdado dos seus antepassados. Temos conhecimento deste facto apenas de forma indirecta, por ter sobrevivido um diploma, datado de 29 de Abril de $1074^{98}$, que refere que Loba Nunes e Sesnando Davides doaram a Eita Gondesendes e sua mulher, Elvira Gonçalves, os bens que Nuno havia recebido em Nogueiró, onde era co-proprietário junto com a tia, Gontrode Nunes - a qual, de resto, a 6 de Abril de $1072^{99}$, pouco mais de um ano depois da morte do sobrinho, viria a doar ao mesmo casal a sua metade própria na vila. Antes de adquirir estes bens, o destinatário da doação, Eita Gondesendes, havia feito parte da comitiva de Fernando I e de sua filha, Urraca, em pelo menos três ocasiões, subscrevendo diplomas de doação à igreja de Santiago de Compostela, em que se contemplavam bens situados no vale do rio Lima, a 8 de Janeiro de $1061^{100}$, a 10 de [Junho] de [1065] ${ }^{101}$ e a 25 de Junho de $1066^{102}$. Também a rainha viúva, Sancha, e os irmãos de Urraca, Afonso VI, Elvira, Garcia II e Sancho II, confirmaram a doação a Santiago de Compostela, junto com os bispos Vistruário de Lugo, Paio de Leão e Pedro de Astorga ${ }^{103}$. Eita Gondesendes não era, pois, uma figura estranha às famílias real e condal.

${ }^{98}$ LF 202 (1074.04.29).

${ }^{99}$ LF 201 (1072.04.06).

${ }^{100}$ Tombo A, n. ${ }^{\circ} 68$ (1061.01.08): «Ecta Gundesindiz testis.».

${ }^{101}$ Tombo A, n. ${ }^{\circ} 69$ ([1065.06].10): «Ecta Gundesindiz conf.».

${ }^{102}$ Tombo A, n. ${ }^{\circ} 85$ (1066.06.25): «Ecta Gundesindici conf.».

${ }^{103}$ Tombo A, n. ${ }^{\circ} 85$ (1066.06.25): «Sancia regina conf.»; «Adefonsus rex conf.»; «Geloira eius soror conf.»; «Garsea rex conf. (signum)»; «Santius Federnandi principis filius conf.»; «Vistruarius Lucensis episcopus conf.»; «Pelagius Legionensis episcopus conf.»; «Petrus Astoricensis episcopus conf.». 
Depois da derrota e morte de Nuno, os bens que o conde e a sua tia haviam herdado de Ilduara Mendes em Nogueiró reverteram a favor de um homem que acompanhara o rei de Leão e os seus filhos e que provavelmente também possuía significativos interesses patrimoniais na fronteira do rio Lima, paralelamente a Braga. Tudo indica que Nogueiró - metade por doação de Gontrode Nunes, metade por doação de Loba Nunes e Sesnando Davides - tenha, por este motivo, passado integralmente para a sua posse entre 1072 e 1074, data das duas doações. Nestas circunstâncias, três anos depois da batalha de Pedroso, a vila que constituíra o último centro do domínio regional da família condal portucalense - e onde possivelmente ainda se erguia o paço habitado pelos avós e bisavós de Nuno - se encontrava nas mãos de proprietários leigos sem quaisquer ligações ao último conde de Portucale.

Devemos sublinhar esta questão, na medida em que a concessão patrimonial de Afonso VI a Loba Nunes e Sesnando Davides não foi acompanhada pelo reconhecimento do uso do título de condes pelos herdeiros naturais de Nuno. Não é fácil perceber por que razão isto aconteceu. Se considerarmos que este silêncio resultou de uma opção do casal, tal facto poderá ser entendido como uma tentativa de distanciamento de Loba Nunes e Sesnando Davides relativamente às consequências políticas que a sublevação do conde contra o rei deve seguramente ter implicado. Por agora, importa apenas sublinhar que o silêncio do casal relativamente à possibilidade de se lhes ser politicamente reconhecido o uso do título de condes parece vir ao encontro da função que ambos desempenhavam como representantes da autoridade régia leonesa no território de Entre-Douro-e-Mondego, desde a conquista de Coimbra por Fernando I.

Como se percebe, essa reivindicação só poderia ser feita por quem tivesse alguma relação de parentesco e consanguinidade com Nuno, o que, logicamente, colocava Loba Nunes e Sesnando Davides numa situação de clara vantagem por comparação com qualquer outro membro da família condal portucalense. À excepção destes, a única possibilidade de reivindicação do título de conde recaía sobre os filhos da tia paterna de Nuno, Gontrode Nunes, nomeadamente o filho primogénito de Vasco, Nuno Vasques, que se mantivera ao lado do conde no último acto público que antecedeu a batalha de Pedroso. Uma vez que Nuno não tinha irmãos, e que, aparentemente, o seu segundo tio paterno, Múnio Nunes, também não deixou descendência, as únicas soluções possíveis para a perpetuação do título passavam, por um lado, pela sua filha e genro, ou, por outro, pelo seu primo.

No entanto, o silêncio das fontes quanto a este facto permite-nos pensar que nem Loba Nunes, nem Nuno Vasques, primos em segundo grau, demonstraram qualquer interesse em assegurar as funções anteriormente reservadas a Nuno. 
Tal facto poderá não só reflectir o progressivo esvaziamento do poder que tinha sido apanágio da agora obsoleta nobreza condal, como até traduzir uma situação de algum desconforto dos familiares mais próximos do conde, relativamente a uma situação política que, depois da batalha, talvez tenha sido encarada com algumas reservas pelas autoridades do reino. Este aspecto ajuda-nos seguramente a explicar a forma como Sesnando Davides, enquanto representante de Afonso VI, deve ter encarado a possibilidade de ver alargada a sua jurisdição a uma região dominada por famílias que ainda mantinham algumas afinidades com Nuno, mas que, após a sua morte, pouco ou nenhum interesse devem ter demonstrado em perpetuar a memória de que ainda mantinham ligações ao último conde de Portucale. 